UDC 330.46: 005.591.3

http://doi.org/10.21272/mmi.2019.1-09

Classification: B49, C63, D89, 010

\author{
Valentyn Rach, \\ D.Sc., Professor, «KROK» University, Ukraine \\ Olga Rossoshanska, \\ D.Sc., Associate Professor, Lugansk State Academy of Culture and Arts, Ukraine \\ Olena Medvedieva, \\ D.Sc., Professor, «KROK» University, Ukraine \\ Alona Yevdokymova, \\ Ph.D., Sumy State University, Ukraine
}

\title{
SYSTEM MODELLING OF DEVELOPMENT OF INNOVATIVE PROJECT-ORIENTED ENTERPRISES
}

Abstract. The article summarizes the arguments and counterarguments within the scientific discussion on the quantification of various spheres of enterprise activity based on their system representation. The main purpose of the study is to improve the basic model of systemic economics as the basis for developing a method for quantitative assessment of the harmonious process of development of innovative project-oriented enterprises. Systematization of literary sources and approaches to solving the problem of choosing a basic model has shown that the most reasonable and developed approach is based on the model of the economic tetrad. Various authors used the model when developing indicators of balance and stability of economic systems. However, the known results were not compared, and the model was not used to describe the innovative development of enterprises. The urgency to solve this scientific problem is in the fact that in the era of knowledge economy, innovation development is becoming one of the main directions of activity of modern enterprises, which needs the scientific ground. Studying of the point related to creation of a method for quantitative assessment of the innovative project-oriented enterprises development is carried out in the following logical sequence: making the economic tetrad matching requirements of the system integrity and completeness; conducting an analysis of resource interchange in the triad of the economic tetrad; revealing the essence of the mechanism for managing processes of growth and development of enterprises; developing a mathematical apparatus to describe the dynamic structural changes of enterprises; conducting a computer experiment using five different approaches to calculating the indicators of dynamic structural changes during the introduction of innovations; conducting a comparative analysis of the results. The methodical toolkit of the research considers the postulates of systematicity, scale, harmony, and positions of qualitative mathematics and the triple convolution method. The object of the study is the selected phases of the innovation project life cycle since they determine the peculiarities of the dynamic structural changes of enterprises during the introduction of innovations. The article presents the results of the empirical analysis, carried out based on computer modelling of the innovation project implementation within six different approaches. This showed a fundamentally different nature of the change in structural balance indicators for these approaches. The study theoretically proves and empirically confirms that the proposed indicator of the internal coherence of opposite actions (chaotic and organized) corresponds to the logic of the harmonious implementation of innovation activity. The results of the study can be applied when creating monitoring and management systems for the development of innovative project-oriented enterprises.

Keywords: balance, harmony, implicit phenomena, innovation project, triple convolution method.

Introduction. There has been wide discussion on the crisis of economic theory during last two decades in the world economic science. The discussion revealed that it is impossible for economic science to perform its main functions such as descriptive, explanatory and predictive on the basis of the existing methodological and theoretical basis. One of the reasons for such a situation is caused by historical lag in the average of 100 years of the paradigm of economic science from the paradigms of natural science (Rybachuk, 2016). The reduction of this lag may be achieved by such a methodological resource, as systematic studies of the economy (Platonova et al., 2012). Therefore, the processes of reforming the conceptual positions of economic theory based on the system paradigm, the main attributes of which were

Cite as: Rach, V., Rossoshanska, O., Medvedieva, O., \& Yevdokymova, A. (2019). System Modelling of Development of Innovative Project-Oriented Enterprises. Marketing and Management of Innovations, 1, 105-131. http://doi.org/10.21272/mmi.2019.1-09 

Oriented Enterprises

formulated by J. Kornai are aimed at it (Kornai, 1999). Suggested system paradigm as a reaction to transformation processes at the macro-level has expanded the limits of its application to meso- and microlevels (Goroshkova et al., 2016; Kleiner, 2002). The obtained theoretical findings allowed G. Kleiner to distinguish a new direction of the economic theory, i.e. systemic economics within which the positions of the main economic paradigms (neoclassical, institutional, evolutionary and systemic) and the economic systems theory in the context of the spatial-temporal approach are integrated (Kleiner, 2013).

In parallel with the processes of reforming the conceptual positions of economic theory in the real sector of the economy there were observed large-scale processes of globalization, significant development of the intellectual property market, the birth of technological revolutions «Industry - 3.0, 4.0», etc. Modern economy is determined by five main areas of activity: science, innovation, production, trade and consumption (Leontyev, 2015). Basically, R\&D became the core of enterprises' activity due to the fact that the elasticity of investment into R\&D is significantly higher than into the real economy. So, for example, the elasticity of investment is $10.6 \%$ in the companies of IT-sector of the USA (Petrova et al., 2013). According to the data of the World Intellectual Property Organization, the most successful modern companies obtain more than $75 \%$ of the effect by means of scientific and technological advances and less than $20 \%$ is received by managing finances, assets, capital through cost parameters (Leontyev, 2015). Annually, the item of income from the sale of patented intellectual property objects makes about 150 billion dollars in the USA, which is about $12 \%$ of GDP. For comparison, income from oil sales amounted to 90 billion dollars in Russia in 2015 (Martseva, 2014). This indicates that knowledge and innovation have become the basis of the modern economy. But the issues of innovation at various large-scale levels of the economy were episodically considered within the systemic economics.

In such conditions, innovative project-oriented (IPO) enterprises become the most effective and competitive, economically safe in strategic terms. They differ in their hybrid organizational structure, flexible management of projects portfolio while implementing innovations as separate businesses with purpose to create new values for consumers (Rossoshanska, 2017). The specific character of such enterprises is that they are constantly in a state of innovative development due to the continuous parallel implementation of innovations that are at different phases of the life cycle. Therefore, the issues of dynamic structural and functional balance are the most relevant ones for IPO enterprises. Currently, within a systemic economy, balance is considered as a characteristic of the economic system, and equilibrium as a characteristic of their state during functioning, i.e. the implementation of the main functions of production, distribution, exchange and consumption. However, the balance characteristics have not yet been determined and have not been investigated in the implementation aspect of the innovative development function.

These facts demonstrate the lack of the integral consideration of issues of the innovative development management of IPO enterprises within the systemic economics.

Literature Review. The problems of the theory of systemic economics were investigated not only by G. Kleiner (Kleiner, 2013) but also by B. Leontyev (2015), A. Voroshan (2014), V. Sytnikov (2012) and others within the different epistemic spaces, various ontological and methodological positions. The difference, first of all, is seen in the interpretation of such basic categories as «system approach» and «system». It causes the emergence of different contextual vision of the essence of the systemic economics, its theoretical foundations, methods and tools. Such a vision is determined by the subject of systemic knowledge.

Thus, B. Leontiev's system approach is based on the consideration of research objects as part of larger systems and as independent systems with all important elements and functions. At the same time knowledge about these systems is combined in the mode of statics and dynamics. The hierarchical levels of the economy from individuals (as subjects of economic relations) to the mega economic interstate relations and institutions of relations (WTO, WIPO, UNWTO, WHO, etc.) are the context vector of the 

Oriented Enterprises

consideration of systemic economics according to B. Leontiev. The legal influence of the latter on the subjects of economic relations becomes more and more powerful in the modern knowledge economy (Leontyev, 2015). A. Voroshan also considers economics as a large system consisting of systems. He presents system economics as a process of interconnected interaction of humanic systems, as well as set of other visible and invisible (energy-information) systems. Interaction takes place with the aim of hedonization as a mechanism for the providing and developing humanic systems. However, the mechanism of interaction and relationships in such systems remains unrevealed (Voroshan, 2014). An analysis of the most well-known approaches to the implementation of the system approach allowed V. Sytnikov to prove that J. Kornai, while writing the «System Paradigm», was guided not by explicit provisions about the impossibility of establishing clear boundaries between the spheres of social life and «closing» the economy in the rigid framework (Sytnikov, 2012).

A similar diversity state of the interpretation of systems and the system approach is observed in system management while considering the processes of innovative development. This is confirmed by the analysis of research of such well-known scientists and practitioners as W. Deming (2006), H. Neave (2014) R. Ackoff (2002), P. Senge (2009), D. Garaedagi (2010) and others.

Today, the issue of quantitative evaluation of various spheres of enterprise activity is the least developed in the theory of system economics and system management. S. Voytko and M. Kravchenko suggested to use the indicator of economic stability to characterize the machine-building enterprises within the neo-system paradigm (the author's definition of the approach developed by G. Kleiner and his colleagues). According to their hypothesis «the stability of the enterprise as economic system of microlevel is determined by the level of balance of its four subsystems of different types» (Voytko et al., 2017). At the same time, in their opinion, the «ideal» balance and the highest level of economic stability is achieved under the condition of the equal expressiveness of subsystems. M. Rybachuk suggested to use the index of system balance of the structure to characterize the enterprises' strategic stability. The index takes into account the assessment of the system structure proportions and the characteristics of the intensity of the relations between the subsystems, which are determined by the graphical modelling method (Rybachuk, 2016). The calculation and interpretation of the structural balance index was carried out using the formula proposed by G. Kleiner (Kleiner, 2014). Just as in the research of S .Voytko and M. Kravchenko, an interval scale was used to evaluate and interpret the estimates, which does not take into account the nonlinear character of the change in the indices of any system.

The issues of innovative development are widely considered within the concept of the triple helix of $\mathrm{H}$. Etzkowitz, which by its essence is also systemic (Etzkowitz, 2010). Examples of the successful implementation of this concept are the economic miracles of South Korea (Lukyanenko et al., 2013) and Singapore (Romanov, 2015). From the standpoint of the concept of a triple helix, N. Smorodinskaya proved that only those formations where an innovative space arises, and not just an agglomeration effect, become a real growth pole with a continuously growing conceptual force (Smorodinskaya, 2011). And based on the model of the fractal triple helix, I. Ivanova and co-authors showed that such a model can be applied to any economic system, regardless of its scale (Ivanova et al., 2011). Within the system-integral vision of a triple helix, we suggested a structure of an innovation system based on institutes of triple helix, which was supplemented by innovative enterprises cluster (Rach et al., 2011). This allowed revealing the essence of the relations between the elements of the innovation system as the basis of the mechanism for implementing the triple spiral model for innovation in the scale of regions and states.

The abovementioned scientific facts make possible to suggest that problems of the systemic economics and system management should not be divided but considered holistically from unified methodological positions. The first positive results of this approach are confirmed by the research of G. Kleiner (2008b). This is the holistic approach that should be considered today as a priority and be used while considering the development of, first of all, innovative project-oriented enterprises. The major focus 

Oriented Enterprises

should be placed on the application of mathematical methods, first of all, qualitative one during the process of the further development of the provisions of the systemic economics and management. Their advantage is shown in some of the abovementioned research (Voytko et al., 2017; Rybachuk, 2016).

Methodology. The research is devoted to the further development of the basic models of the systemic economics for the possibility of its application for the management of growth processes and the innovative project-oriented enterprises development, as well as the development of the method of quantitative representation of the system structuring of such enterprises during these managing processes from the position of system management. To achieve the goal, the following tasks we set. The first one is to align the basic model of the systemic economics of the economic tetrad, to the requirements of system integrity and completeness. The second task is the disclosure of the essence of the mechanism of managing the processes of growth and development of enterprises, including innovative project-oriented ones. The third one is the development of mathematical apparatus for describing the dynamic structural changes that occur in the economic tetrad during the process of innovations implementation.

Any research is carried out within the specific epistemological space that is a multidimensional conceptually differentiated abstract-logical integrity. The structure of the epistemological space characterizes the scientific position of the researcher concerning the specific features of the interpretation of the object and subject of research (Medvedev, 2005). Therefore, the multiplicity of existing epistemological equivalent spaces of researchers-economists nowadays must be considered as system defining factor in modern economics, which guarantees its development.

The epistemological space of this research is based on the postulate of consistency, which means following: everything that is perceived by a person arises in his/her mind in the form of designed target system models of the universum (integrity), which at the same time take into account integrity greater by scale and integrities less by scale which form continuum. The following consequences follow from the consistency postulate. A system is knowledge about the whole, a way of representing the reality that is made up by interdependent objects of natural and artificial origin. Knowledge is not the essence of things, but systems. The simultaneous consideration of greater integrity and integrities, which form a continuum, determines the essence of the system approach, and it is its distinguishing feature among other approaches, in particular, the complex one. In this research, we do not use the term «hierarchy», because we believe that there are no objects or processes in nature that meet the excellent features of the hierarchy. But the term «scale» will be used to reflect different levels of consideration of the continuum.

The research is based on the provisions of qualitative mathematics, which provides the study of geometric images (Barlybaev et al., 2015). «Qualitative mathematics is used in economic research in cases when economic relations are easier to present in the form of geometric relations» (Orekhov, 2009). Today, most of the research within systemic economics has been conducted using the methods of qualitative mathematics (Kleiner, 2011b; Kravchenko, 2017). In qualitative mathematics, the term "accuracy» is considered as a measure of the observed phenomenon definiteness that is enough to distinguish it from other phenomena (Poljancev, 1973). Accuracy is not related to the quantitative characteristics of the phenomenon, but with the qualitative ones.

Results. Let us proceed from the given starting points to the solution of the first task of the research - to ensure the compatibility of the basic model of systemic economics of economic tetrad in compliance with the requirements of system integrity and completeness. The basic graphical element of systemic economic is the economic tetrad (Figure 1). The elements of the tetrad are the basic types of economic systems («environment», «process», «project» and «object»). Each of these systems has features of all types of systems. The distinguishing feature of the systems is the presence or absence of constraints of the space-time continuum. Constraints are functional, and do not define the structural limits of an economic tetrad as a whole. 
V. Rach, O. Rossoshanska, O. Medvedieva, A. Yevdokymova. System Modelling of Development of Innovative ProjectOriented Enterprises

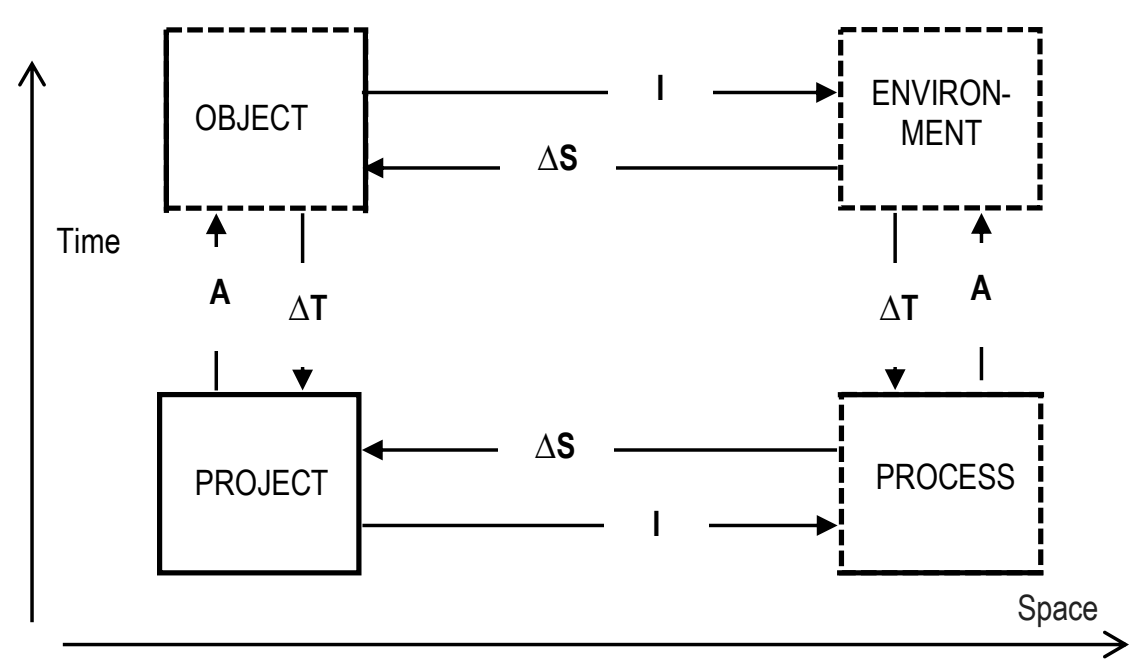

Source: (Kleiner, 2011b).

Figure 1. Economic tetrad

The tetrad has a peculiar ring-shaped structure, the elements of which are connected with symbiotic mutual relations (Kleiner, 2013). At the same time, the pairs «project-environment» and «process-object» do not directly interact with each other in this structure. This does not correspond to the representation of the system as a holistic integrated entity. The system representation of the whole provides the existence of mutual relations between all elements of the tetrad (Rossoshanskaya, 2000). To implement this requirement, it is necessary to add relations between the specified elements of the tetrad to the model and establish the interaction between them. The integrity factor is the result according to the provisions of functional systems (Anokhin, 1973). But the model has no structural limits of the whole. Therefore, it is not clear where the result comes from and what is the reason for its occurrence. According to the general provisions of the system approach, each of the elements of the system simultaneously belongs to the studied system and to other systems that are located in the external environment of this system. Therefore, the model of economic tetrad should reflect the distinction between these systems.

Figure 2 shows a model of economic tetrad without the abovementioned non-compliances with system requirements. It was added with new relations and the element «limit» was introduced without which the target system model of the continuum cannot be constructed.

The model shows that the three-pronged objective of the activity of the tetrad is determined by the essence of its relations with the other three tetrads, which are elements of greater integrity. And the essence of each element of the studied tetrad is revealed by presenting it as a tetrad of a smaller scale.

A model of economic tetrad can be used to describe the activities of economic entities of different scale, capable of functioning independently, and which have the processes of production, consumption, distribution and exchange (Kleiner, 2013). These processes constitute operational activities for entities of micro-level. But apart from this activity, each subject also conducts growth and development activities. According to the definition of R. Ackoff, growth is associated with such a phenomenon as an increase in size or number, and development - with the emergence of qualities that reflect new organizational skills and competence (Ackoff, 2002).

The development always takes place due to the innovation's implementation (George et al., 2006). For project-oriented enterprises, the source of innovation is the internal environment where the conditions are created for the creative work of creative employees (Rossoshanska, 2015). However, from the position 
V. Rach, O. Rossoshanska, O. Medvedieva, A. Yevdokymova. System Modelling of Development of Innovative ProjectOriented Enterprises

of the systemic economics, the spreading and implementation of innovations are considered as diffusion processes of the external environment.

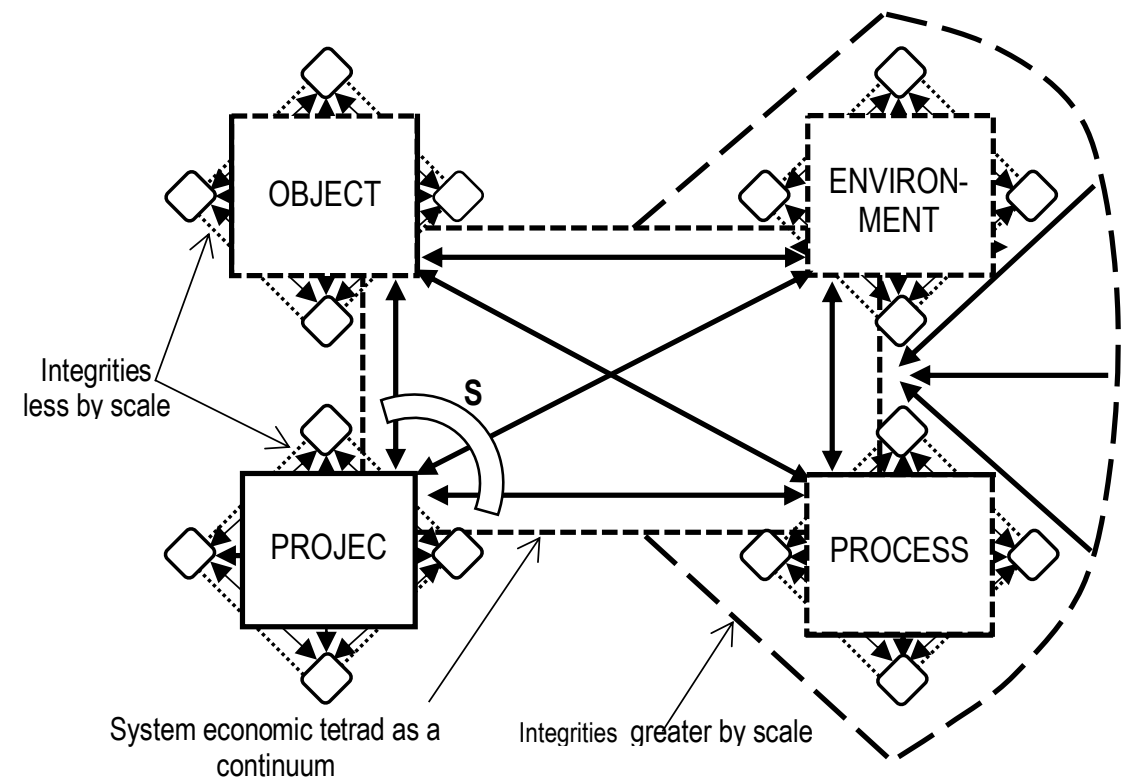

Figure 2. Representation of economic tetrad within system approach

Source: compiled by authors.

According to $\mathrm{G}$. Kleiner, the condition for the innovative development implementation should be a double system encapsulation of the innovation project. First, an innovation project must be equipped with a «system shell» that creates an economic system around the innovative structure. Further, this system should be included into the tetrad, which provides the interaction of all four types of economic systems and ensures this innovation (Kleiner, 2011b). Such encapsulation is graphically reflected by the model in Figure 2 by integrities smaller by scale. «System shell» is considered as a set of relations through which the component «project» interacts with other elements of the system tetrad. It is conventionally marked with the symbol S in Figure 2. To clarify the features of the system shell, let's consider the economic tetrad, where the limit is added and the relations between the subsystems «project - environment» and «process - object» are revealed (Figure 3). As one can see, added relations are much more complex than in the ring-shaped part of the model. It is reasonable to consider both models in Figure 2 and 3 as the basic models of a systemic economics that meet the requirements of system integrity and completeness.

To solve the second task of the study, i.e. the disclosure of the essence of the mechanism for managing the processes of growth and development of enterprises, including innovative project-oriented ones, we will first conduct a study of the model (Figure 3) from the standpoint of activities related to growth. According to the logic of the system approach, each element of the tetrad is a system that at the same time is a subsystem with respect to the tetrad. From these positions, it is reasonable to clarify the abovementioned definition of the term «growth» using the following terms of the economic tetrad: growth is an increase of the economic subsystem «object» in size or in quantity without changing the qualitative properties of the tetrad as an integral economic system. Why did we choose the subsystem «object»? The economic subsystem «object» has limitations to the spatial base resource and unlimited use of the temporary basic resource. 


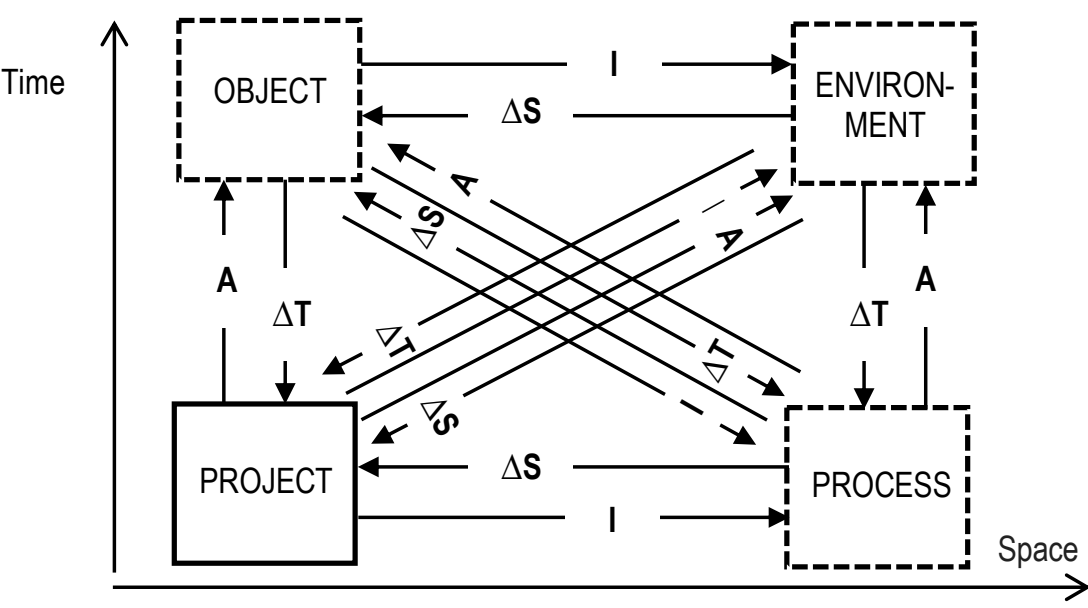

Figure 3. System model of economic tetrad

Source: compiled by authors.

At the same time, it has such an energy resource as intensity. Growth and development require targeted activity of the subsystems of the economic tetrad which are aimed at overcoming the corresponding limitations. The «object» has spatial limitation. Based on the model in Figure 3, activities on growth will be added with the relations between the «process» and «object» that were additionally brought into the communication model. Due to this, the «process» can transfer to the «object» the spatial resource available for it without limitation and part of its energy resource, i.e. activity. While using these resources, the «object» overcomes its spatial limitation, due to which it increases in size. In addition, this corresponds to the essence of growth. To reveal the essence of such a process, let us present the growth in the form of two triads (Figure 4), which are built based on the model in Figure 3. As one can see, growth occurs with the participation of the «object» and «process» simultaneously in two systemic triads: G1 «object - process - project» and G2 «object - process - environment».

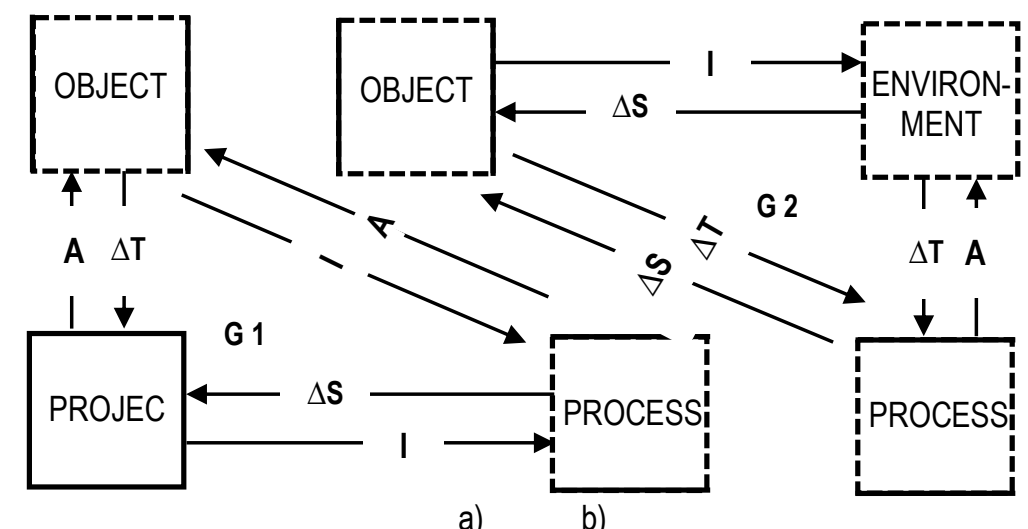

Figure 4. Resource exchange processes during the growth within triads $\mathrm{G} 1$ uobject - process project» (a) and $\mathbf{G} 2$ «object- process- environment» (b)

Source: compiled by authors. 

Oriented Enterprises

The first triad performs an organizational function, stimulating an increase in the activity $(A)$ of the «object» and the intensity (I) of the «process». These incentives are additional ones in comparison with the operational activities. Due to this, there is a mutual exchange of energy resources that are necessary for each economic subsystem. These additional resources reinforce similar resources which the «object» and «process» receive from the «project» during the implementation of operational activities. The «object» receives additional energy support for the activity, and the «process» receives additional energy support for the intensity. The described process of interaction between the economic subsystems of the triad corresponds to the essence of the intercoaction between them (the term was suggested by P. Anokhin (1973).

The second triad performs the function of providing the growth process of basic resources due to their mutual exchange between economic subsystems. The increase in the spatial resource of the «object» by means of the temporary resource of the «process» is due to their redundancy: the spatial one during the «process» and the temporal one relates the «object». At the same time, just as during operational activities, «process» receives from the «environment» an additional time resource, and the «object» - the spatial one.

The developed model shows that growth of «object» and "process» requires additional basic resources - spatial and temporal, respectively. In addition, it is necessary to ensure the transfer of not only these resources, but also energy during the growth. These processes occur in parallel and do not have a strong relation. Therefore, during growth, there may occur the situations of structural imbalance, when there will be a "redundancy» of basic resources and a shortage of energy resources or vice versa. On the basis of the analysis of the model, we can conclude that during growth there can be no rapid and significant changes in the economic tetrad. This is due to the fact that the "object» has no limitations of the temporal resource availability. Therefore, it does not need an additional intensity resource, which determines the rate of change. «Object» does not naturally need it to perform its main economic function. Quite the contrary, the «object» is getting deprived of this resource by its transfer to the «process» and «environment». If situations, that require a quick response to growth, arise in practice, they are economically dangerous and require special methods for their detection, analysis and estimation.

In contrast to growth, development provides the occurrence of the property of the economic tetrad to increase the ability and desire to meet the own growing needs and «legal» desires, as well as the needs and desires of other tetrads. This statement is formed using the term «development» proposed by R. Ackoff (2002) and the terms that are used while considering the economic tetrad. «Legal» desires are those desires, which can be satisfied at the expense of the own capabilities of the tetrad, without creating obstacles to the development of other tetrads. It follows that development is always associated with an increase in the ability and competencies of the tetrad as an integral economic system. Development determines the qualitative changes in the economic tetrad. This can happen only due to the element «project». The specific feature of the «project» as an economic subsystem is the complete limitations of the basic temporal and spatial resources. At the same time, the «project», unlike other subsystems of the tetrad, possesses two energy resources at the same time - intensity and activity. Due to it, the projects are the source of innovative development, which is a significant distinctive feature of IPO enterprises.

According to the model in Figure 3 , the development is stimulated by the intercoaction of two economic subsystems: the «project» and «environment». The «environment» subsystem has limitations diametrically opposed to the «project» limitations. The «environment» has no limitations to the spatial and temporal basic resources. At the same time, this subsystem has no energy resources that ensure the use of space (intensity) and time (activity). (Linking of intensity to space and linking of activity to time were proposed by G. Kleiner (Kleiner, 2011a)). This contrast of subsystems determines the specific features of development activities. 

Oriented Enterprises

The subsystems «project» and «environment» are simultaneously presented in two systemic triads: D1 «project - environment - object» and D2 «project - environment - process» (Figure 5).

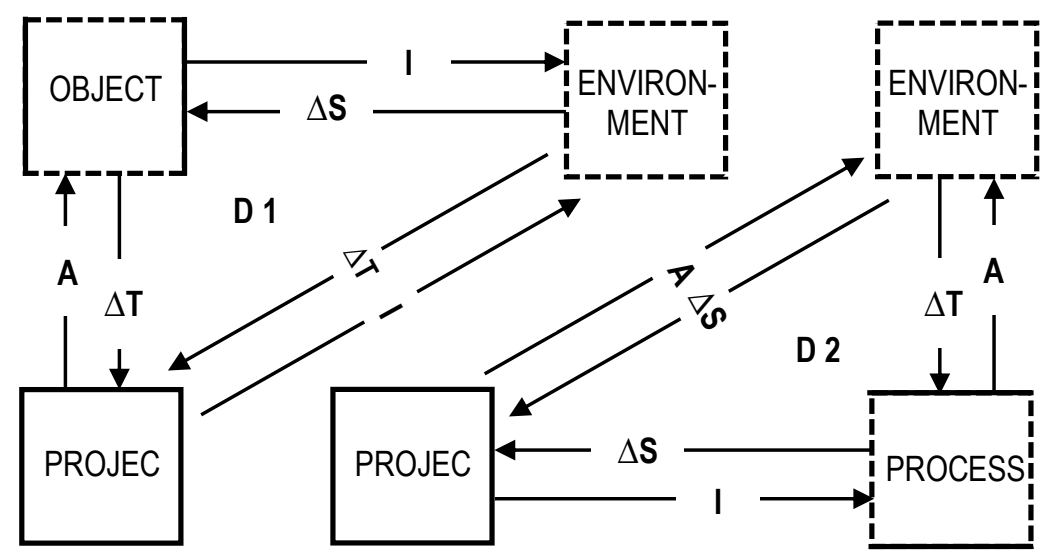

a)

b)

Figure 5. Resource exchange processes during the growth within triads D1 «project environment - object» (a) and D2 «project- environment- process» (b)

Source: compiled by authors

Triad D1 reflects the processes of obtaining an additional temporal resource $\Delta \mathrm{T}$ by the «project» from the «environment» due to the delivery of the energy resource of activity from «project» to the «environment». During the implementation of operating activities, "project» receives the temporal resource only from the «object». And the additional receiving of $\Delta T$ is a natural reaction of the «environment» to the increase in activity caused by the «project». Due to $\Delta T$, the first basic requirement for IPO enterprise is implemented in an economic tetrad, i.e. to be always able to implement the innovation faster than its current and potential competitors (George et al., 2006). Receiving an additional temporal resource allows fulfilling another requirement that is contained in the modern concept of innovative business model, i.e. the ability to be more responsive to instability than competitors (Dyachkova et al., 2016).

There is also observed additional receiving resource by «project in the triad D2. The «project» receives additional basic spatial resources $\Delta \mathrm{S}$ from the «environment» due to the fact that the «project» transfer energy resource «intensity» to the «environment». This exchange makes it possible to fulfill one more basic requirement for IPO enterprises, i.e. a constant increase in efforts and resources aimed at identifying and analyzing the possibilities of the market space. Professional implementation of this requirement allows obtaining "consumers' knowledge» concerning their needs earlier than their competitors. And this provides receiving high marginal income in future by reducing the time at the stage of the innovative project initialization and significant differentiation at the stage of its development. Considering an organization as a living organism K. Meyer and S. Davis also pointed out the necessity of time reduction and differentiation while implementing innovations through innovation project implementation (Meyer et al., 2007).

It should be noted that the additional receiving of only one basic resource (time or space) does not provide a significant competitive advantage. It is possible to obtain positive synergistic effect only with a balanced increase of both resources. This requirement is fulfilled due to the simultaneous joint Intercoaction of the systemic triads D1 and D2 (Figure 5).

Comparison of the resource exchange processes during growth and development shows that they are completely different not only in the composition of economic subsystems, but also in essence of the 
V. Rach, O. Rossoshanska, O. Medvedieva, A. Yevdokymova. System Modelling of Development of Innovative ProjectOriented Enterprises

exchange processes. During growth in the economic subsystems that determine this activity, there is a concentration of resources of various entities - basic and energy ones. So, the basic spatial resource and the energy resource «activity» are concentrated in the «object» and the basic temporal resource and the energy resource «intensity» are concentrated in the "process» (Figure 6 a). During the development process the economic subsystem «project» gets additional basic resources (time and space) and the subsystem «environment» gets only energy resources («activity» and «intensity») (Figure 6b).

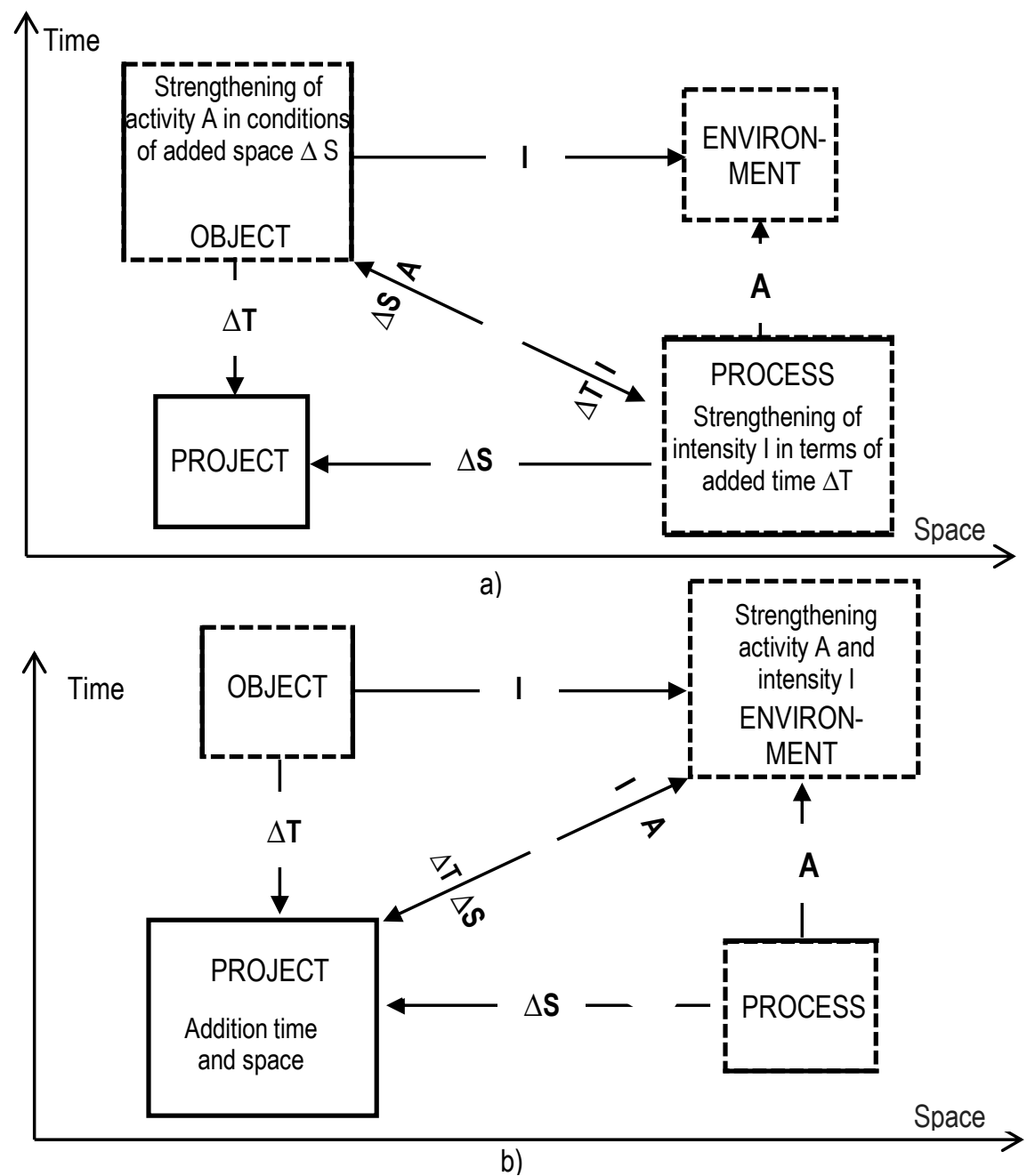

Figure 6. Resource exchange processes during the growth (a) and development (b) between Source: compiled by authors. subsystems of economic systemic tetrad

The success of development and growth is determined not only by the presence of relations between the main system components (during the growth - between «object» and «process» and during the development - between «project» and «environment»), but also by the understanding of what is the root 
V. Rach, O. Rossoshanska, O. Medvedieva, A. Yevdokymova. System Modelling of Development of Innovative ProjectOriented Enterprises

cause of the beginning of the resources exchange. In this regard, we will consider a systemic triad model consisting of such components as «time», «space» and «basic element» of the economic systemic triad (Figure 7).

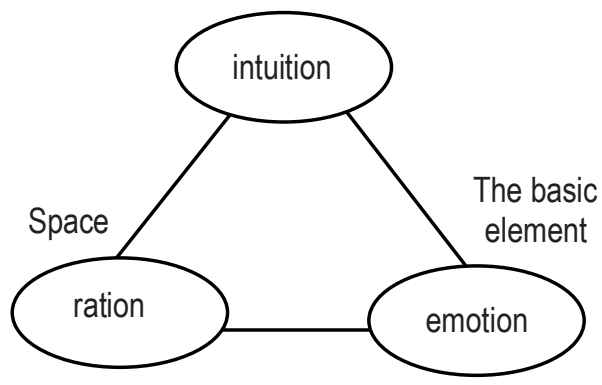

Figure 7. Interrelation of the «ratio-emotio-intuition» triad with the basic resources «time space» and the basic element of the triads of the economic tetrad

Source: compiled by authors.

Such an interrelationship of the components between such elements of the triad as «ratio - emotio intuition» is caused by the following. Innovation (during development) and improvement (during growth) cannot be implemented without emotional support. This support is an incentive for the actualization of energy resources exchange. Therefore, two economic subsystems are the basic elements of motivation during the growth. The subsystem «object» initiates the intensity, and the subsystem «process» initiates the activity. During the development only economic subsystem «project» is an incentive. It is the very thing that activates the emergence of energy resources "activity» and «intensity» in the subsystem «environment».

Regarding the expansion of space. This task is of rational choice, based on a fairly «moderate» calculation. The emotional component is not needed here. It will only prevent to make rational choice as spatial structures are much more stable than their emotional perception. However, it is impossible to rationally solve the space expansion task without understanding that there is a possibility in economic tetrad to actualize the transfer of the energy resource «intensity» between the subsystems.

An intuitive sense of the timeliness of the start of such activities is necessary to spend time on growth or development. It is impossible to save and then use the time as a resource. That is why its use requires an energy resource «activity».

The described specific features of the interaction between the subsystems using the suggested basic model of a systemic economics (Figure 3 ) have revealed the essence of the mechanism for managing the growth and development of enterprises, in particular, innovative project-oriented ones. That is a ground to proceed to the solution of the third task of the research - the development of a mathematical apparatus for describing the dynamic structural changes that occur in the system during the activity on innovations implementation. To solve it, we use the provisions of the harmonization concept. It was presented in the form of the law of harmony by K. Adametsky, who is one of the founders of the theory of scientific management along with F. Taylor (Adametsky, 1972).

Despite the ambiguous attitude to the application of the harmony laws in scientific research, it is impossible to deny the positive results of their introduction to real economy (Ivanus, 2013; Sharipova, 2012). Over the past ten years, a harmonious approach began to develop rapidly. This is reflected in the relevant scientific publications (Kleiner, 2008a; Muratov, 2012; Vartsaba, 2015; Barmashov, 2018). Such changes coincide with the general trend, which, according to $\mathrm{G}$. Kleiner, consists in a fact that global 

Oriented Enterprises

economic crises forced many economists to start revising the basic essence concepts, limits and factors of the economy (Kleiner, 2012). According to A. Galchynsky, the undertone of revising basic concepts is the inadequacy of the existing methodological tools of the previous eras to adequate attempts to substantiate fundamentally new phenomena of social development (Halchynskyi, 2006). In our opinion, the new methodological tool should be based on the trinity of harmonious, fractal and system approaches. This does not contradict $\mathrm{G}$. Kleiner's opinion that interdisciplinarity, systemicity and harmony guide the development of socio-economic research (Kleiner, 2015b).

Within the harmonious approach, K. Adametsky identified three types of harmony: in arrangement, in action and spiritual harmony (Adametsky, 1972). From a position of system approach they must also be considered in the trinity. The rather high level of abstraction and the natural psychological unpreparedness of perception of the above listed approaches require deciding on the basic provisions, each of which has its own contextual basis during mathematical apparatus development.

Regarding the interpretation of activities in the context of harmony of action. Activities should be considered as an integral activity of organized and chaotic actions, the implementation of which makes the participants feel a sense of harmony/disharmony depending on the relative share of these actions as the whole while achieving the objective of the activity. The sense of harmony is inherent only to personality and reflects the internal state. Internal state is measured by a person's sense of comfort/discomfort. It is difficult to express in words. But comfort manifests itself in the results of harmonious activity. Employees in a harmonious state have significantly higher indicators of efficiency and effectiveness compared with the results achieved by employees in a state of disharmony.

Regarding the essence of the components and system structure in the context of harmony of arrangement. The understanding of the distinctive features of the terms «part» and «element» is crucial for this task solving. To do so, we use the definitions suggested by H.P. Shchedrovytsky for describing systems. Any object of research (local universum) can be represented as a set of components. The term «parts» will denote the components (small universums), which are formed by the destruction of the object of research. Parts can be put together to reproduce the static parameters of the object (shape, size, etc.). But the functions of the object won't be reproduced. The term «elements» will denote components that have relations between themselves. They are included in the structure and are organized by the system structure. Their internal existence in the structure of the whole is caused by the relations between them. And they function in the structure only due to the relations (Shhedrovickij et al., 2012). Based on this, it can be concluded that the system structure simultaneously determines both the manifestation of the functional qualities of the elements and the quality of the studied object as a whole.

Regarding measurement metric in the context of spiritual harmony. An appropriate metric is needed to describe an activity using a system model. It should allow obtaining the numerical value of a certain property of the system that correlates with the sense of spiritual harmony/disharmony of the participants involved in the implementation of a specific target activity. At the same time, the metric should take into account the structure of the system, its composition, components as elements (harmony of arrangement), as well as internally systemic relations between elements (harmony of action). In addition, it should reflect the interrelation of organizational and chaotic actions and correlate with a sense of harmony of integral activity. Taking into account these conditions will allow obtaining the numerical value of a system property that will characterize not an explicitly manifested activity connected with a local universum, but the one that defines this activity. Such property cannot be directly perceived and measured. It, just like harmony, belongs to the phenomena that exist, but there are invisible to the senses, to the field of implicit knowledge. Therefore, they are called implicit phenomena, which include implicit knowledge (Osipov et al., 2004), entropy (Osipov et al., 2004) and many other phenomena.

Regarding the interpretation of the numerical value of a system property in the context of harmony/disharmony. It is logical to use of a nodal line of measures, which is a canonical quantitative 

Oriented Enterprises

relationship within the limits of unit interval. They are known as «generalized golden ratio» (GGR) (Soroko, 2011). If the numerical value of the property coincides with one of the GGR, then it is believed that the system is in the state of optimal functioning, and its intrastructural diversity is harmonized. And if the value is midway between the GGR, the system is in a pathological state (Knyazeva, 2016). Accordingly, any inharmonious state of activity must be brought to intrastructural harmonization of meaningfully opposite actions - organized and chaotic ones. It should be emphasized that, according to O. Muratov's classification, the GGR belong to the two-dimensional harmonious approach (Muratov, 2012). It is reasonable to expand it to the four-dimensional approach (by the number of elements in the economic tetrad). For this purpose, one can use the best practices obtained by V. Vladymyrov and O. Stakhov on the basis of revising the theory of turning sequences in the "whole-greater-less» triad, that is related to golden ratio (Vladimirov et al., 2011).

Regarding the terminological designation of the numerical value of a particular property of the system. Practice shows that the use of already known terms to designate another entity leads to a multiplicity of notions, an increase in ambiguity and the appearance of contradictions in the interpretation of texts with their use. The most dangerous is the expansion of the application of the term to fields where such use has led to the emergence of paradoxes. In 1968, A. Molchanov, professor, director and founder of the Scientific Research Computing Center of Academy of Sciences of the USSR, noted that «words such as «probability» and «entropy» are so overloaded with the history of science, random associations that must be decisively removed from usage» (Molchanov, 1968). But over the past sixty years, the state of the use of these terms beyond the scope of their primary subject areas has expanded further. Therefore, the use of so-called «objective» entropies inevitably leads to confusion and contradictions (Gidlevsky, 2011; Kochetkov et al., 2015). In the classical understanding, the concept of entropy emerged due to the principle of observation (Chepkasov et al., 2014). Therefore, for a holistic description of the internal consistency of opposites, the neutral term «ICLU» we introduce instead of term «entropy». ICLU is an internal characteristic of the property of a local universum, which depends on the purpose of its activity, which, in its turn:

- is demonstrated to the observer in the form of external changes in the activities of the universum;

- reflects the limited internal diversity of the universum that are not controlled by the consciousness of the observer;

- is calculated on the basis of the representation of the universum in the form of a system model that is built by the observer;

- reflects the state of internal consistency of opposites;

- allows to form (assess) judgments about the degree of harmony/disharmony of its state by the criterion of compliance with the nodal line of measures (nodal correlation of measures).

To develop a mathematical apparatus for calculating ICLU on the basis of a model of an economic tetrad, we introduce the symbolic notation of its elements and the relations between them (Figure 8). The elements are marked by indices which were suggested by $\mathrm{G}$. Kleiner for the corresponding types of basic economic subsystems (environment, process, project and object) (Kleiner, 2011b).

To denote the various relations between the subsystems of the tetrad, we used the superscript and subscript right indices. The subscript marks the elements between which the relation is studied, and the superscript indicates the type of relation that is taken into account when solving a specific task. When considering general theoretical issues, the superscript is not used. ICLU for an enterprise is its characteristic as an integral entity (universum), which reflects the subjective, intuitive target sense of harmony of its internal structure which the researcher (observer) feels, and it is calculated based on the use of economic tetrad model. 


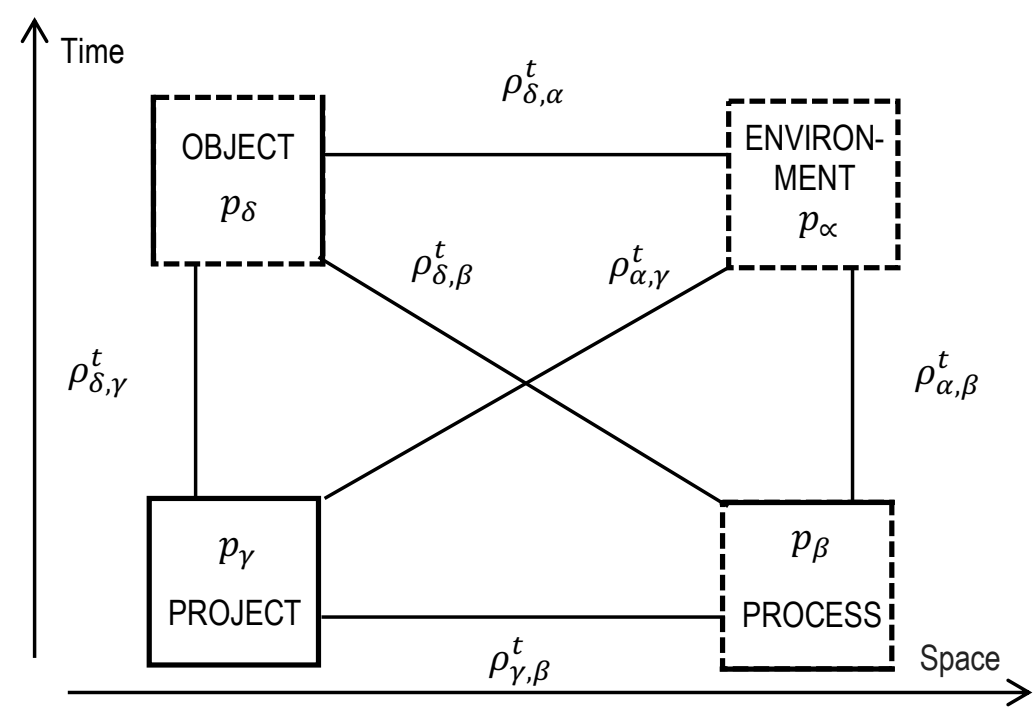

Figure 8. Symbolic model of economic tetrad, which reflects the development activities Source: compiled by authors.

Therefore, there can be many ICLU for one enterprise. The reason is the existence of a variety of both research objectives and indicators describing the activities of the enterprise. But all of them will be calculated using function that is invariant to any changes, in general form it has the following view:

$$
I C L U=F\left(f\left(p_{\alpha} ; g\left(\rho_{\alpha i}\right)\right) ; f\left(p_{\beta} ; g\left(\rho_{\beta i}\right)\right) ; f\left(p_{\gamma} ; g\left(\rho_{\gamma i}\right)\right) ; f\left(p_{\delta} ; g\left(\rho_{\delta i}\right)\right) ; q\left(\Delta_{i, j}\right)\right)
$$

where: $p_{j} \geq 0$-specific weight of $j$ - element in tetrad; $\rho_{\mathrm{j}, I}$ - characteristic of the relation of $j$ - element with $j$ - element of tetrad; $\mathrm{q}(\Delta i j)$-structure of tetrad in a form of information on the relations between elements; $\Delta_{i j}=1$ - if the relation is available, $\Delta_{i j}=0$ - if the relation is absent; $i=\{a, \beta, \gamma, \delta\}$, for function $f$ with the exception of index of specific weight of the $j-$ element.

Let's assume that in any situation the elements of an economic tetrad are quantitatively represented in a standard form, which requires the fulfillment of the following condition

$$
p_{\propto}+p_{\beta}+p_{\gamma}+p_{\delta}=1
$$

At the same time, an additional condition is imposed on the structure, which is connected to the necessity to take into account the importance of the components while implementing a specific objective of the activity. Such condition can be represented as a finite scheme.

$$
A=\left(\begin{array}{llll}
A_{\propto} & A_{\beta} & A_{\gamma} & A_{\delta} \\
p_{\alpha} & p_{\beta} & p_{\gamma} & p_{\gamma}
\end{array}\right)
$$

where: $A_{j}-j$ rating of $j$ - element, which reflects its importance for achieving the objective of activity at the corresponding phase (stage) of the activity; $p_{j}$ - value of specific weight of $j$ - element at the corresponding phase of the activity. 

Oriented Enterprises

As can be seen, the objective function (1) is quite complex, since its nature of change is determined by five components. Each component of objective function is also a function, four of them describe one of the subsystems in the structure of the tetrad (function - component), and the fifth is function structure. Each of these functions should reflect the implementation options for the limited internal diversity of the interaction of the subsystem with other subsystems in a particular tetrad structure, taking into account limitations (2) and (3).

The basis of the function-component is also a function that describes the nature of the relation of one subsystem with other elements of the tetrad (the function-relationship). The exact form of the functionrelationship is unknown. We will consider the relation between the subsystems as a psychophysiological process. This assumption was made on the grounds that any interaction between elements in actual practice is carried out through the participants of particular activity. The type of relation has no crucial significance. Information is the most important thing in this process. Despite the ambiguity of the existing approaches to the definition of its essence (Senatorov, 2018), it can be unambiguously stated that information has the dual nature. According to the postulate of the dual nature of information, it has material (functional) and logical components (Skryl', 2008). The material component relates to the fact that information provides information about objects and phenomena that are transmitted through control channels. The logical component relates to the peculiarities of human thinking that is associated with different perceptions of the same information by different persons. It is the logical component that reveals the limited diversity that is peculiar to any universum. Limited diversity always relates to uncertainty. For a person, uncertainty is an irritant, and the manifestation of one of the variants of limited diversity is a surprise. According to the Weber-Fechner law, the power of sense of a person is proportional to the logarithm of the intensity of the irritant (Ovchinnikiv et al., 2017). Apparently, it was a reason that R. Hartley intuitively suggested to determine the amount of information by the logarithm of the total number of possible messages (in our understanding - limited diversity) (Vyatkin, 2004). His assumption was based on the fact that the quantitative measure of information should be consistent with the intuitive concepts of the information content in the message.

From the perspective of our research, information determines the essence of the relation between the subsystems of the tetrad. It is an irritant for the subsystems. Based on this, it is reason to assume that the function-component will obey the Weber-Fechner empirical psychophysiological law. Therefore, functioncomponent can be represented as follows

$$
f\left(p_{j} ; g\left(\rho_{j i}\right)\right)=\log \left(p_{j} ;\left(g\left(\rho_{j i}\right)\right)\right)
$$

It is logical to assume that the function-relation $q q\left(\rho_{j, i}\right)$ will depend on the specific weight of elements between which this relation exists. And the less difference between specific weights, the greater probability of manifestation of limitation of internal diversity of interactions between such elements. It means that function-component has maximum absolute value at the minimum value of the function-relation. Based on this, the characteristic of communication is determined not by specific gravities but by their difference. This difference has different effects on structures of tetrad with different specific weights of its elements. To take into account this statement, we normalize the differences between the elements with respect to the maximum possible difference in the specific structure of the tetrad. The following formula corresponds to the logic of reasoning.

$$
g\left(\rho_{j i}\right)=1-\frac{\left|p_{j}-p_{i}\right|}{\max \left(p_{j}\right)-\min \left(p_{j}\right)}
$$



Oriented Enterprises

Theoretically, the function-relation reaches a maximum value that is close to 1 , in case when the elements have the same specific weight.

To get the value of function-component according to (4), it is necessary to define the convolution operation. Weighting coefficients are often used for this purpose. Weighting coefficients are the parameters of the specific weight of elements in the structure. For example, such an operation is widely used to calculate the entropy according to the geometric convolution procedure (B-entropy) (Leus, 2003). Nevertheless, such variant of convolution introduces an additional unreasonable effect of the attribute characteristics of the system elements on the characteristics of the relation between them, which are calculated by the formula (5). This leads to a distortion of characteristics. Another way is the calculation of arithmetic averages (Gini, 1970). However, it is known that different averages are used for different variants of ordered elements of the sample, which differ in the nature of changes in the ratios of differences between neighboring elements (Orlov, 2013). Real structures, which correspond to the elements of the tetrad, have a significant difference in the value of the specific weight. If calculate the different averages for them, then the value of such averages will differ significantly.

To overcome this effect, we use the method of triple convolution, which was developed in the research (Rach et al., 2017). At the first stage, it provides the calculation of four types of power averages (harmonic $\bar{a}_{h}$, geometric $\bar{a}_{g}$, arithmetic $\bar{a}_{a}$, and quadratic $\bar{a}_{r}$ ) based on the values of the function that is convoluted. In our case, this is the value of the relation characteristics $\rho_{\alpha, \beta}, \rho_{\alpha, \gamma^{\prime}}$ and $\rho_{\alpha, \delta}$ At the second stage, the same calculations for the obtained values of the power averages are carried out. This procedure is repeated two more times. As a result, the value of all averages converges to the same value. It is proved that such triple convolution has the property for converging for any values of the structural parameters of the system. The received value, in its essence, is a characteristic of the implemented variant of the limited internal diversity of interaction between the elements for a particular system structure. During the convolution of functions, which can take a value close to zero, and then are to be taken to the logarithm (our variant), it is advisable to use two power averages arithmetic $\bar{a}_{a}$, and quadratic $\bar{a}_{r^{-}}$. For the mathematical notation of triple convolution, we use the positional two-sided form of the operator's record, which for an economic tetrad will be as follows

$$
G_{i}={ }_{i, j} \bar{Q}_{a, r}^{3}\left(\rho_{i, j}\right),
$$

where: $i=\operatorname{const}(\alpha$, or $\beta$, or $\gamma$, or $\delta), j=\propto, \beta, \gamma, \delta$, excl.value $i$

The fifth function is $q\left(\Delta_{i j}\right)$ in the formula (1). Its task is to take into account the features of the structure of the tetrad in the form of information about the presence of relations between its elements. When implementing innovation projects, the structure consists of two contours (Figure 5). Each contour contains three components. Such elements of the tetrad as «project» and «environment» are included to each contour. Their participation in each contour can be taken into account by conditional dividing these elements into two parts, one of which interacts with the element «object», and the second one with the element «process». The divisibility rule should be established depending on the situation of the activity. They can be a control effect in an innovation project. One of the variants of the rule can be built on the Pareto principle: $80 \%$ of the elements interact with an element with a large rank, and $20 \%$ with the rest. It is also possible to divide in proportion to the specific weights of the object and process elements.

Continuing the logic of triple convolution, we use it to reveal the structure of formula (1). In the final version, the invariant function of ICLU calculation has the following view 
V. Rach, O. Rossoshanska, O. Medvedieva, A. Yevdokymova. System Modelling of Development of Innovative ProjectOriented Enterprises

$$
\operatorname{ICLU}={ }_{k} \bar{Q}_{a, r}^{3}\left(p_{k}\left({ }_{i} \bar{Q}_{a, r}^{3}\left(p_{i} \log \left({ }_{i, j} \bar{Q}_{a, r}^{3}\left(1-\frac{\left|p_{j}-p_{i}\right|}{\max \left(p_{j}\right)-\min \left(p_{j}\right)}\right)\right)\right)\right)\right.
$$

where: $p_{k}-$ specific weight of contours.

From the analysis of formula (7), it can be seen that ICLU is determined by the values of specific weight of the elements of the tetrad and contours. That is, the formula takes into account the peculiarities of the organizational structure of the enterprise, the type of activity (functioning, growth or development) that is studied, the content and scope of monitoring the activity, the rules for the division into contours. For example, these may be rules for the exchange of basic or energy resources between elementssubsystems, targeted information about innovation. Due to the economic tetrad, like any other model, the researcher has the information about the structure of the tetrad, its elements and relations, regardless of the purpose of the research.

Let's apply ICLU to study the process of innovation implementation through the innovation projects implementation. To do this, we use two models. The first one is the model for presenting an innovation project by the phases of its implementation (column 4 of Table 1). Phase names are not typical for project management. They are built by synthesizing and grouping the phases that are the most often used in research and innovation implementation (George et al., 2006; Samoldin, 2015; Zemtsov et al., 2016).

Table 1. Rating of elements of tetrad at different phases of innovation project

\begin{tabular}{|c|c|c|c|c|c|c|c|}
\hline \multirow[b]{2}{*}{ No. } & \multicolumn{2}{|c|}{ Energy costs } & \multirow{2}{*}{$\begin{array}{l}\text { Phases of innovation } \\
\text { project and products } \\
\text { of their completion }\end{array}$} & \multirow{2}{*}{\begin{tabular}{|c|} 
environment \\
$A_{\alpha}$ \\
\end{tabular}} & \multirow{2}{*}{$\begin{array}{c}\text { process } \\
A_{\beta}\end{array}$} & \multirow{2}{*}{ project } & \multirow{2}{*}{ object } \\
\hline & current & total & & & & & \\
\hline 1 & & & \multicolumn{5}{|c|}{ Appearance of innovation idea as reaction to weak market signals } \\
\hline $1-2$ & 1 & & R\&D & 2 & 3 & 1 & 4 \\
\hline 2 & & 1 & \multicolumn{5}{|c|}{ Prototype providing ability to create innovative production } \\
\hline $2-3$ & 1 & & Market testing & 1 & 3 & 2 & 4 \\
\hline 3 & & 2 & \multicolumn{5}{|c|}{ Identified needs and potential market volume, its differentiation } \\
\hline $3-4$ & 2 & & $\begin{array}{l}\text { Design preparation of } \\
\text { production }\end{array}$ & 3 & 4 & 2 & 1 \\
\hline 4 & & 3 & \multicolumn{5}{|c|}{ Prototype } \\
\hline $4-5$ & 3 & & $\begin{array}{l}\text { Technological } \\
\text { preparation of } \\
\text { production }\end{array}$ & 3 & 1 & 2 & 4 \\
\hline 5 & & 6 & \multicolumn{5}{|c|}{ Commercial sample } \\
\hline $5-6$ & 5 & & $\begin{array}{l}\text { Organizational } \\
\text { preparation of } \\
\text { production }\end{array}$ & 4 & 1 & 3 & 2 \\
\hline 6 & & 11 & \multicolumn{5}{|c|}{ First customer } \\
\hline $6-7$ & 8 & & $\begin{array}{l}\text { Organization of } \\
\text { distribution and } \\
\text { exchange }\end{array}$ & 1 & 2 & 4 & 3 \\
\hline 7 & & 19 & \multicolumn{5}{|c|}{ Full production } \\
\hline
\end{tabular}

Source: compiled by authors. 
V. Rach, O. Rossoshanska, O. Medvedieva, A. Yevdokymova. System Modelling of Development of Innovative ProjectOriented Enterprises

The second model is the S-curve model of innovative development, which corresponds to the harmonious flow of internal development processes (Rossoshanska, 2015). The model is based on the use of Fibonacci numbers and indicates the relative intellectual costs (human capital, etc.) by the phases of the innovation project (columns 2, 3 of Table 1). The joint use of two models allows determining the importance of tetrad elements by expertise at different phases of innovation project. The importance is fixed by the corresponding rating (columns 5-8 of the Table 1). Depending on the type of implementation of innovations (product, process, marketing or managerial) and the characteristics of the organization of project activities at the enterprise, the ratings between the components will vary. Changes in ratings can occur during the implementation phase. However, the general approach to their definition remains unchanged. The rating characterizes how the activity and intensity of an element of tetrad should change at the corresponding phase relative to the basic state of activity of elements of the tetrad at the initial phase. Imagine the specific weight of each element by analogy with (Molchanov, 1968) as the sum of two functions - dominant and fluctuant

$$
p_{i}=p_{i}^{d}+p_{i}^{f}
$$

The dominant remains constant for the duration of the innovation project. Fluctuant varies depending on the rating of the element at the corresponding phase. It is small relative to dominant. Therefore, to determine it, we use the Pareto principle. We assume that the sum of the dominants of all elements of the tetrad is unchanged during the project implementation, corresponds to the basic state of the system and is 0.8 . At the same time, the specific weight of dominants of each element also remains unchanged. Then the amount of fluctuant will make 0.2 and the specific weight of each element at each phase of the project will be determined by its rating. Let's fix for each rating the first numbers of the Fibonacci series, starting with one in the reverse order (Table 2).

Table 2. Value of fluctuant for elements of tetrad depending on their rating

\begin{tabular}{|c|c|c|c|}
\hline Rating & Fibonacci numbers & $\begin{array}{c}\text { Specific weight in } \\
\text { rating line }\end{array}$ & Fluctuant \\
\hline 1 & 5 & 0,455 & 0,091 \\
\hline 2 & 3 & 0,273 & 0,055 \\
\hline 3 & 2 & 0,182 & 0,036 \\
\hline 4 & 1 & 0,091 & 0,018 \\
\hline
\end{tabular}

Source: compiled by authors.

To make a model of the project implementation, four schemes of dominants were generated by phases (Table 3).

Table 3. Value of dominants of economic tetrad with different specific weights of its elements

\begin{tabular}{|c|c|c|c|c|c|}
\hline \multirow{3}{*}{ Scheme No. } & \multicolumn{4}{|c|}{ Specific weight of dominant of tetrad elements } & \multirow{3}{*}{$\begin{array}{c}\text { Sum of } \\
\text { specific } \\
\text { weight }\end{array}$} \\
\hline & $\alpha$ & $\beta$ & $Y$ & $\delta$ & \\
\hline & environment & process & project & object & \\
\hline 1 & 0,05 & 0,11 & 0,625 & 0,015 & 0,8 \\
\hline 2 & 0,0857 & 0,1886 & 0,5 & 0,0257 & 0,8 \\
\hline 3 & 0,1214 & 0,2671 & 0,375 & 0,0364 & 0,8 \\
\hline 4 & 0,1571 & 0,3457 & 0,25 & 0,0471 & 0,8 \\
\hline
\end{tabular}

Source: compiled by authors. 
V. Rach, O. Rossoshanska, O. Medvedieva, A. Yevdokymova. System Modelling of Development of Innovative ProjectOriented Enterprises

Structures are generated in such a way that the maximum weight of the element «project» is uniformly reducing from 0.625 to 0.25 . This allowed getting schemes with a different basic ratio of the specific weight of the elements. In the fourth scheme, the specific weight of the process exceeds the weight of the project.

Analysis of the ICLU values, calculated by the formula (7), showed that for all four schemes the general nature of the change is identical: growth at the second phase, decrease up to the fifth phase and increase at the sixth phase (Figure 9). Identity is confirmed by the high value of the correlation coefficients between the schemes (0.7-0.99), except for the third and fourth schemes (0.45). Such ICLU change is logical. Entry into the market with a prototype model increases the internal inconsistency between the elements due to the appearance of new information from the external environment. This is information about the service requirements of potential consumers regarding future innovative products, its differentiation in order to identify the best functionality for customers, etc. The implementation of the phases of designing, technological and organizational preparation increases internal consistency between tetrad elements. The increase in inconsistency is manifested again at the phase of distribution and dividing. This period is full of problems concerning with bringing output of production to planned targets. The problems are connected with the issues of harmonization of the internal and external environment. And it always causes the increase in the inconsistency between the elements. However, it is possible to talk about the criticality of inconsistency after comparing the ICLU values with the values of the GGR (the dashed lines in Figure 9). Note, that the GGR are designed for two-component systems.

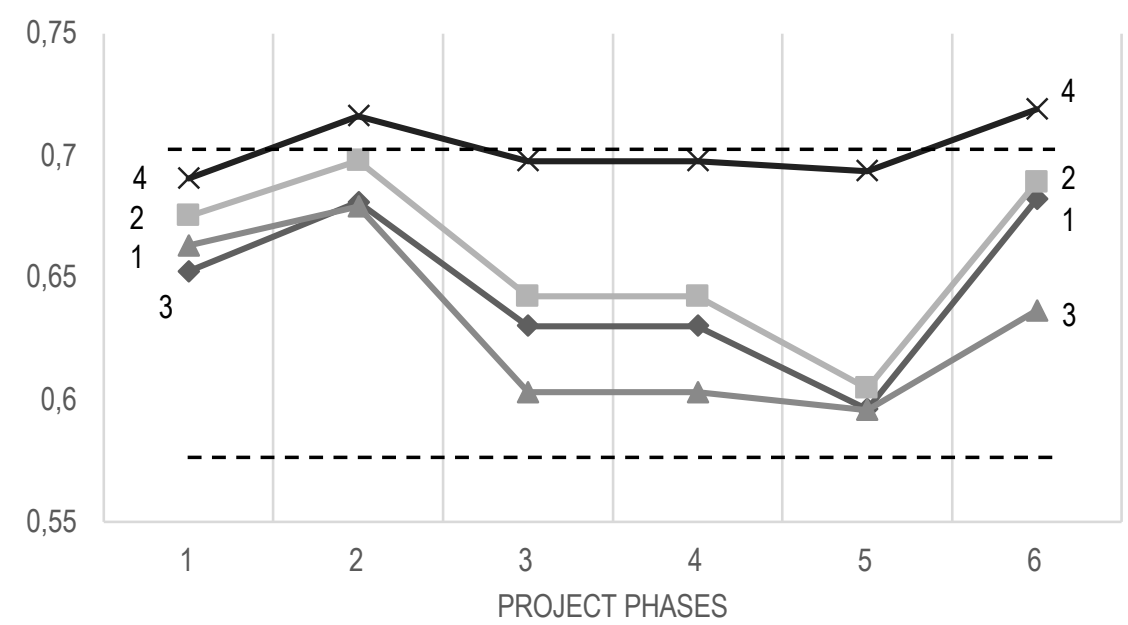

Figure 9. Dependence of change of ICLU by phases of innovation project

Note: the number of lines corresponds to the number in Table 3.

Source: compiled by authors.

It is necessary to use the best practices to find the closest to the calculated ICLU values of the «golden ratio» for further correction of the structural parameters of the tetrad (Vladimirov et al., 2011). From this perspective, one can consider ICLU as a parameter for measuring the degree of harmony of the tetrad structure. In different researches, the parameter similar to ICLU has different names and formulas, such as: Index of economic sustainability (Soroko, 2011)

$$
H=-\frac{1}{\log n} \sum_{i=1}^{n} p_{i} \log p_{i}
$$


Index of systemic balance (Leus, 2003; Dulesov, 2010)

$B_{\rho}(p)=-\sum_{i=1}^{n} p_{i} \log \sum_{j=1}^{n}\left(1-\rho_{i j}\right) p_{j} ;$

Index of economy balance (Kleiner, 2015a)

In $=\frac{1}{\left(\frac{a}{b}+\frac{b}{a}+\frac{a}{c}+\frac{c}{a}+\frac{a}{d}+\frac{d}{a}+\frac{b}{c}+\frac{c}{b}+\frac{b}{d}+\frac{d}{b}+\frac{c}{d}+\frac{d}{c}-11\right)} ;$

Harmony criteria (Rybachuk, 2016)

$E n=\frac{\left(\left|\frac{a}{c}-1\right|+\left|\frac{d}{b}-1\right|+\left|\frac{d}{a}-1\right|\right)}{\left(\left|\frac{a}{c}-1\right|+\left|\frac{d}{b}-1\right|+\left|\frac{d}{a}-1\right|+1\right)} ;$

Measure of uncertainty (Kravchenko, 2017)

$E n=1-\sqrt{\frac{(a-0,5)^{2}+(b-0,5)^{2}+(c-0,5)^{2}+(d-0,5)^{2}}{2,1716}}$.

For formulas (9) and (10) $i=\propto, \beta, \gamma, \delta ; y=\propto, \beta, \gamma, \delta$. For formulas (11), (12) and (13)

$$
\begin{aligned}
& a=\sqrt{\left(1-y_{0}\right)^{2}+\left(x_{0}-C\right)^{2}} ; \quad b=\sqrt{\left(y_{0}-F\right)^{2}+\left(1-x_{0}\right)^{2}} ; \\
& \mathrm{c}=\sqrt{\left(\mathrm{y}_{0}\right)^{2}+\left(\mathrm{L}-\mathrm{x}_{0}\right)^{2}} ; \quad \mathrm{d}=\sqrt{\left(\mathrm{x}_{0}\right)^{2}+\left(\mathrm{A}-\mathrm{y}_{0}\right)^{2}} ; \\
& x_{0}=\frac{L-A(L-C)}{1-(A-F)(L-C)} ; \\
& y_{0}=A-\left(\frac{L-A(L-C)}{1-(A-F)(L-C)}\right)(A-F) ; \\
& A=\frac{p_{\gamma}}{p_{\gamma}+p_{\delta}} ; \quad B=\frac{p_{\delta}}{p_{\delta}+p_{\gamma}} ; \quad C=\frac{p_{\delta}}{p_{\delta}+p_{\alpha}} ; \quad D=\frac{p_{\alpha}}{p_{\alpha}+p_{\delta}} ; \\
& E=\frac{p_{\alpha}}{p_{\alpha}+p_{\beta}} ; \quad F=\frac{p_{\beta}}{p_{\beta}+p_{\alpha}} ; \quad K=\frac{p_{\beta}}{p_{\beta}+p_{\gamma}} ; \quad L=\frac{p_{\gamma}}{p_{\gamma}+p_{\beta}} .
\end{aligned}
$$

The above-mentioned parameters are based on different approaches to obtaining working formulas for their calculations. We do not know an approach, which would not be based on the associative application of similar mathematical expressions from other fields of knowledge or on geometric interpretation of the systems parameters. Therefore, it is necessary to compare the results of calculations obtained by formulas (9-13) for identical structures of tetrad. Scheme 2 (Table 3 ) was chosen as the basic structure. The advantage of this scheme for the task is that its ICLU indicators are located midway between the indicators of other schemes. That is, there will be no questions about the influence of the boundary zones of the indicators. 
V. Rach, O. Rossoshanska, O. Medvedieva, A. Yevdokymova. System Modelling of Development of Innovative ProjectOriented Enterprises

The analysis of indicators by the phases of the innovation project showed the lack of relation between the nature of their changes and the logic of changes by the phases, which is described above (Figure 10). This is evidenced by the values of the correlation coefficients between ICLU and other indicators (Table 4).

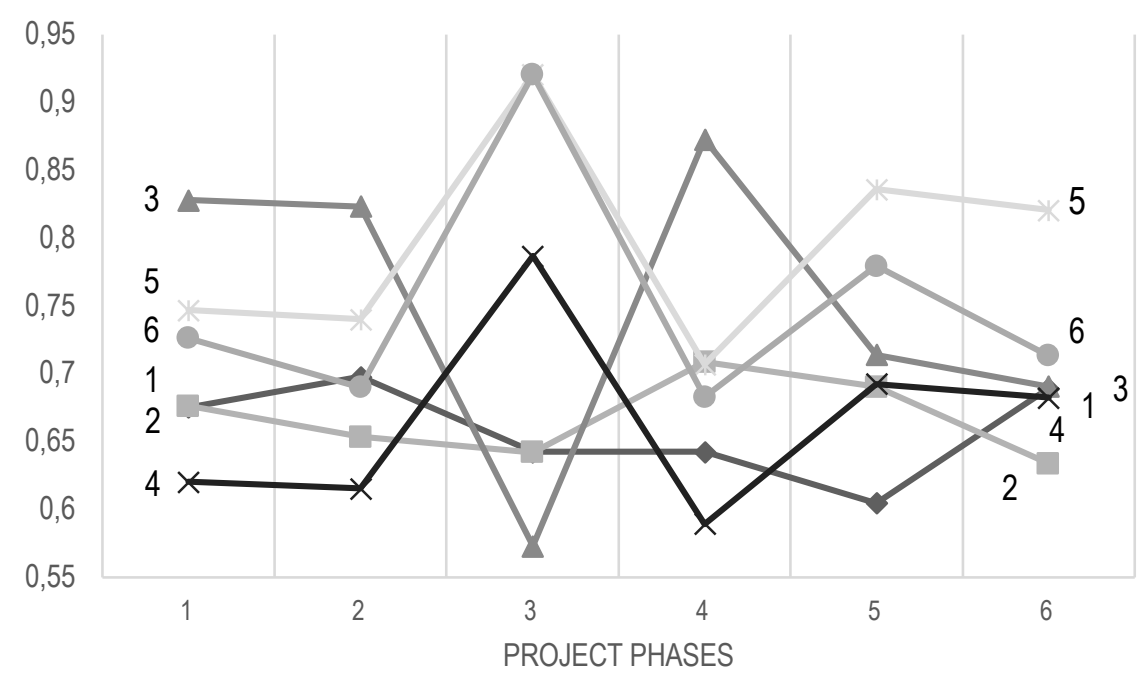

Figure 10. Dependence of changes of various indicators by the phases of the innovation project Note: the number of lines corresponds to the number in Table 4.

Source: compiled by authors.

Table 4. The values of the coefficients of correlation between the values of the indicator of measuring the degree of harmony of the structure of the tetrad calculated by different formulas

\begin{tabular}{|c|c|c|c|c|c|c|c|c|}
\hline № & Source & Formula & $\mathbf{1}$ & $\mathbf{2}$ & $\mathbf{3}$ & $\mathbf{4}$ & $\mathbf{5}$ & $\mathbf{6}$ \\
\hline 1 & (this article) & $(7)$ & $\mathrm{X}$ & $-0,57$ & 0,26 & $-0,35$ & $-0,36$ & $-0,45$ \\
\hline 2 & (Rybachuk, 2016) & $(12)$ & & $\mathrm{X}$ & 0,64 & $-0,56$ & $-0,56$ & $-0,35$ \\
\hline 3 & (Kleiner, 2015a) & $(11)$ & & & $\mathrm{X}$ & $-0,99$ & $-0,99$ & $-0,87$ \\
\hline 4 & (Kravchenko, 2017) & $(13)$ & & & & $\mathrm{X}$ & 0,99 & 0,93 \\
\hline 5 & (Soroko, 2011) & $(9)$ & & & & & $\mathrm{X}$ & 0,91 \\
\hline 6 & (Leus, 2003) & $(10)$ & & & & & & $\mathrm{X}$ \\
\hline
\end{tabular}

Source: compiled by authors.

Regarding the formula suggested by G. Kleiner (Kleiner, 2015a). Unfortunately, it does not meet the requirements mentioned in this research. Therefore, while constructing graphs, the absolute values of indicators were used in situations when calculations gave a minus sign. In practice, functional dependence between the indicators calculated by formulas (9) and (12) requires further research. This is due to the fact that the methods for creating formulas are based on a crucially different basis. Formula (9) is based on a graphical interpretation of the balance of the structure, and formula (12) is based on Shannon's formula for calculating the information entropy.

Conclusions. An improved system model of an economic tetrad serves as the methodological basis for organizing safe activities in a strategic dimension for IPO enterprise, which builds its economic activity on the implementation of a portfolio of projects with flexible management technology. The mechanism of activity is based on the fact that development is related to the revitalization of the project for transferring 
such energy resources as intensity and activity to the «environment». This is manifested in the transfer of information on the creation of new innovation products, the need for which is defined by the subsystem «environment» and the subsystem «project». The increase in intensity ensures the reduction of the time for receiving the project innovation product, and the increase in activity - the development of a new space (new markets and/or consumers), which requires a new project product. New product is just needed, it is not implemented. Therefore, it is necessary to have some intuition not to lose the chance to come to a customer when he will really need new product and, most importantly, he will purchase it. Otherwise, the business falls under the expression: «You are not late with your product, but market does not need it any more».

The improvement of the theory of systemic economics through the development of conceptual models of growth and development made it possible to disclose in sufficient detail the mechanisms of such activities of IPO enterprises. The consistency and system nature of the developed models, the correspondence of the essence of their elements to the model of minimum integrity of «ratio-emotiointuitio» contributes to their further use as a scientifically confirmed fact.

The introduction of neutral parameter ICLU, as an integral characteristic of the internal consistency of opposites between elements of economic systems, has eliminated the ambiguity of using the existing terms entropy or negentropy. There was disclosed the essence of the components of the formula for ICLU calculation by using the Weber-Fechner law and the Pareto principle. The invariant formula for ICLU calculation has been shaped due to the application of the method of triple convolution of structural indicators of a system model of an economic tetrad.

The procedure for presenting the structural indicators of tetrad elements in the form of two components - dominant and fluctuant - was used as a means of implementing innovations while conducting computer modelling of changes in ICLU during the process of innovation project implementation. This allowed determining the invariant nature of the change in ICLU at the phases of innovation project for various combinations of structural indicators of tetrad elements. Modelling the changes of five indicators that were proposed by other researchers and that are similar to ICLU, showed no correlation between their changes and the invariant character of changes in ICLU.

The issues that need further research are as follows: the use of ICLU in the context of changes in integrated resources in the innovation project implementation, the development of a metric measurement of the level of harmony/disharmony of internal consistency of opposites between the elements of economic systems based on the nodal line of measures. The main issue remains the disclosure of the essence of the exchange of basic (time and space) and energy (activity and intensity) resources between elements of the economic tetrad during the innovation projects implementation. In addition, it is advisable to decide on the list of contexts for which it is advisable to calculate ICLU with purpose to have a holistic view of the degree of harmonization of certain activities.

Author Contributions: conceptualization, V.R. and O.R.; methodology, V. R., O. R. and O. M.; supervision, V. R.; investigation, V. R., O. R., O. M. and A. E.; formal analysis, V. R. and A. E.; validation, O. R. and O. M.; visualization, V. R. and A. E.; writing-original draft preparation, V. R. and O. M.; writing review and editing, V. R.

\section{References}

Ackoff, R. L. (2002). Akoff o menedzhmente [Ackoff about Management]. (L. A. Volkova, Trans). Saint Petersburg: Piter Economy

Adametsky, K. (1972). O nauke orhanizatsii [About the science of organization]. (A.N. Sukhoruchenko, Trans). Moscow:

Anokhin, P.K. (1973). Principial'nye voprosy obshhej teorii funkcional'nyh sistem [Principal issues of the general theory of functional systems]. Printsipy sistemnoy orhanizatsii funktsiy. - Principles of the system organization of functions. Moscow «Science», (pp. 5-61). Retrieved from http://www.nemoai.narod.ru/Library/Functional.pdf [in Russian]. 
V. Rach, O. Rossoshanska, O. Medvedieva, A. Yevdokymova. System Modelling of Development of Innovative ProjectOriented Enterprises

Barlybaev, A.A., Sitnova, I.A, \& Yunusova, G.M. (2015). Kachestvinnie i kolichistvinnie metody v ekonimicheskoy nauke: sovremennoie sostoyanie i perspektivi vzaimodeistvia [Qualitative and quantitative methods in economics: current state and prospects for interaction]. Ekonomicheskiy analiz: teoria i praktika. Economic Analysis: Theory and Practice, 32 (431). Retrieved from https://cyberleninka.ru/article/n/kachestvennye-i-kolichestvennye-metody-v-ekonomicheskoy-nauke-sovremennoe-sostoyaniei-perspektivy-vzaimodeystviyal [in Russian].

Barmashov, K.S. (2018). Garmonizacija promyshlennoj i torgovoj politiki predprijatija [Harmonization of an industrial and trade policy of an enterprise]. Vestnik Gosudarstvenyi universitet upravleniya - Vestnik of the State University of Management, 8. Retrieved from https://cyberleninka.ru/article/n/garmonizatsiya-promyshlennoy-i-torgovoy-politiki-predpriyatiya [In Russian]

Barysheva, A. (2010). Impllitsytnye znania kak vneratsionalnyi kohnityvnyi mekhanizm [Implicit knowledge as an non-rational cognitive mechanism]. Ekonomichiskie stratehii - Economic Straegies, 5, 64-69. Retrieved from http://www.inesnet.ru/wpcontent/mag_archive/2010_05/ES2010-05-barysheva.pdf [in Russian].

Chepkasov V.L., \& Mikhailova T.L. Novye smysly poniatia entropii, ili k voprosu o neoklassicheskom variante poniatia entropi [NEW Meaningd of the Entropy Concept, or to the Question About The Non-Classical Option Of The Entropy Concept]. Retrieved from https://files.scienceforum.ru/pdf/2014/6012.pdf [in Russian].

Chepkasov, V.L., \& Mikhailova, T.L. (2015). Novye smysly poniatia entropii, ili k voprosu o neoklassicheskom variante poniatia entropii [NEW Meaningd of the Entropy Concept, Or To The Question About The Non-Classical Option Of The Entropy Concept] Vestnik Voronezhskogo gosudarstvennogo universiteta. Ekonomika i upravleniye - Vestnik of the Voronezh State University. Series: Economics and Management, 1 (68), 140-146. Retrieved from https://elibrary.ru/download/elibrary_23492066_31118142.pdf

Deming, W. (2006). Novaya ekonomika [New Economy]. Moscow: Eksmo [in Russian].

Dulesov, A.S. (2010). Priminenie formuly Shenona I heometricheskoho obobtschenia dlia opredilenia entropii. [Application of the formula of Shannon and geometric generalization for the definition of entropy]. Perspektivy nauky - Prospects of science, 3 (05), 92-95 [in Russian].

Dyachkova, Yu., \& N., Kiseleva, O. A. (2016). Innovatsionnaia biznes model kak osnova konkurentsii na sovremennom stroytelnom rynke. [Innovative Bussines Model as a Basis for Competition on The Modern Construction Market]. Visnyk Donbaskoil derzhavnoii mashynobudivnoii akademii - Messenger of the Donbas State Machine-Building Academy, 3 (39), 31-36. Retrieved from http://www.dgma.donetsk.ua/science_public/ddma/Herald_3(39)_2016/article/8.pdf [in Russian].

Etzkowitz, G. (2010). Troynaya spiral'. Universitety - predpriyatiya - gosudarstvo. Innovatsii v deystvii [Triple Helix. Universities - enterprises - the state. Innovation in action]. A.F. Uvarova (Ed.). Tomsk: Publishing house of Tomsk State University of control systems and radio electronics [in Russian].

Galchinsky, A.S. (2006). Global'ni transformaciï: konceptual'ni al'ternativi. Metodologichni aspekti [Global Transformation Conceptual Alternatives. Methodological aspects]. Kyiv: Lybid' [In Ukrainian]

George Michael, L., Works, D., \& Watson-Hemphill, K. (2006). Stremitytel'nyie innovatsii [Rapid Innovations]. (Trans). Kyiv: Companion Group), 35 [in Russian].

Gidlevsky, A.V. (2011). Paradoksy entropii (spekulativnyi kharakter sovremennoy nauchnoy metodolohii) [Entropy Paradoxes (the speculative nature of modern scientific methodology)], Vestnik Omskogo gosudarstvennogo universiteta - Bulletin of Omsk State University, 4, 199-201. Retrieved from https://cyberleninka.ru/article/n/paradoksy-entropii-spekulyativnyy-haraktersovremennoy-nauchnoy-metodologii [in Russian].

Gini, K. (1970). Srednie velichiny [Average values] (Trans). Moscow: Statistics [in Russian].

Goroshkova, L.A., \& Volkov, V.P. (2016). Systemnyi pidkhid do upravlinnia enerhozberezhennia na mezorivni [System approach to energy conservation management on meso-level]. Visnyk Pryazovskoho derzhavnoho tekhnichnoho universytetu - Journal of Azov State Technical University, 31 (1), 133-139.Retrieved from http://nbuv.gov.ua/UJRN/VPDTU_ek_2016_31(1)_19.

Ivanova, I.A., Karastelev, B.Ya., \& Yakubovsky, Y.V. (2011). Model troynoy spirali i fraktal'naya struktura innovatsionnoy sistemy $v$ prilozhenii $\mathrm{k}$ realizatsii konkretnogo innovatsionnogo [The triple helix model and the fractal structure of the innovation system as applied to the implementation of a specific innovation project]. Vestnik TGEU - Bulletin of TSUE, 57. Retrieved from: https://cyberleninka.ru/article/n/model-troynoy-spirali-i-fraktalnaya-struktura-innovatsionnoy-sistemy-v-prilozhenii-k-realizatsiikonkretnogo-innovatsionnogo-proekta [in Russian].

Ivanus, A.I. (2013). Garmonizacija upravlenija innovacionnym razvitiem jekonomiki na osnove kognitivnoj tehnologii (teorija i praktika) [Harmonization of Management of Innovative Development of the Economy Based on Cognitive Technology (Theory and Practice)]. Extended abstract of Doctor's thesis. Moscow: Financial University under the Government of the Russian Federation.

Jamshid, G. (2010). Sistemnoye myshleniye. Kak upravlyat' khaosom i slozhnymi protsessami. Platforma dlya modelirovaniya arkhitektury biznesa [System thinking. How to manage chaos and complex processes]. Business Architecture Modeling Platform]. Minsk: Grevtsov Books [in Russian].

Kleiner, G.B. (2002). Sistemnaya paradigma i teoriya predpriyatiya [Systemic paradigm and enterprise theory]. Voprosy ekonomiki - Economics question, 10, 47-69 [in Russian].

Kleiner, G.B. (2008a). Jekonomika dolzhna byt' garmonichnoj! [The economy must be harmonious!]. Jekonomika i zhizn' Economy and Life, 19. Retrieved from https://www.eg-online.ru/article/53986 [In Ukrainian]

Kleiner, G. (2008b). Sistemnaya paradigma i sistemnyy menedzhment [System Paradigm and System Management]. Rossiyskiy zhurnal menedzhmenta - Russian Journal of Management, 3 (6), 27-50. Retrieved from http://kleiner.ru/wpcontent/uploads/2014/12/Kleiner_sispsism.pdf [in Russian]. 
V. Rach, O. Rossoshanska, O. Medvedieva, A. Yevdokymova. System Modelling of Development of Innovative ProjectOriented Enterprises

Kleiner, G.B. (2011a). Resursnaja teorija sistemnoj organizacii jekonomiki [Resource Theory of the System Organization of the Economy]. Rossijskij zhurnal menedzhmenta - Russian Management Journal, 3 (9), 3-28. Retrieved from https://cyberleninka.ru/article/n/resursnaya-teoriya-sistemnoy-organizatsii-ekonomiki

Kleiner, G.B. (2011b). Sistemnaia orhanizatsia economiki i problemy rasprostranenia innovatsiy. [The system of organization of the economy and the problems of the spread of innovation]. Vestnik Universiteta, Hosudarstvenniy universitet upravlenia University Messenger, State University of Management, 3, 26-36. Retrieved from http://kleiner.ru/wpcontent/uploads/2014/12/Sistemnaya-organizatsiya-e\%60konomiki-i- problemyi-rasprostraneniya-innovatsiy.pdf [in Russian].

Kleiner, G.B. (2012). O granicah neogranichennogo [About the Limits of the Unlimited]. Voprosy jekonomiki - Economic issues, 2, 140-145. Retrieved from https://doi.org/10.32609/0042-8736-2012-2-140-145 [In Russian]

Kleiner, G. B. (2013). Sistemnaia ekinomika kak platforma razvitia sovremennoy ekonomichekoy teorii [System Economics as a Platform for the Development of Modern Economic Theory]. Voprosy Ekonomiki - Economic issues, 6. Retrieved from http://kleiner.ru/wp-content/uploads/2015/01/Sistemnaya-e\%60konomika.pdf [ in Russian].

Kleiner, G. (2014). Sistemnaya sbalansirovannost ekonomiki: osnovnye printsipy V.kn. Sistemnyy analiz v ekonomike [Systemic Balancing of the Economy: Basic Principles V.kn. System analysis in economics]. (Vols. 1), (pp. 9-18). Moscow: TSEMI RAN. Retrieved from http://kleiner.ru/wp-content/uploads/2016/11/Kleiner.SAvE_.pdf [in Russian]

Kleiner, G.B. (2015a). Hosudarstvo - rehion - otrasl - predpriatie: karkas systemnoy ustoychivosty ekonomiky Rossii.Chast' 2 [State-region-industry-enterprise: the framework of the systemic sustainability of the Russian economy Part 2]. Ekonomika rehionov - Economy of Regions, 3, 9-17 [in Russian].

Kleiner, G.B. (2015b). Mezhdisciplinarnost', sistemnost', garmonija - orientiry razvitija social'no-jekonomicheskih issledovanij [Interdisciplinary, systematic, harmony - guidelines for the development of socio-economic research]. Perspektivy razvitija mezhdisciplinarnyh social'no-jekonomicheskih i gumanitarnyh issledovanij- Prospects for the development of interdisciplinary socioeconomic and humanities research. Reports and presentations of the round table participants (June 24, 2015, Rostov-on-Don), (pp. 12-32), Rostov-on-Don: Publishing House of the Southern Federal University [In Russian]

Kleiner, G.B. (2016). Ustojchivost rossijskoj ehkonomiki v zerkale sistemnoj ehkonomicheskoj teorii (Chast 2) [The stability of the Russian economy in the mirror of the systemic economic theory (Part 2)]. Voprosy ekonomiki - Economics question, 1, 117138. Retrieved from https://elibrary.ru/item.asp?id=25257709 [in Russian].

Knyazeva, E.N. (2016). Innovatsionnaia slozhnost [Innolnnovative complexity]. Saint-Petesburg: Aletheia, [in Russian]

Kochetkov, A. V., \& Fedotov P. V. (2015). O razlichnyh smyslah poniatia «Entropia» [About various meanings of the concept «Entropy»]. Internet zhurnal Naukovedinie - Internet magazine Science studies, 6 (31). Retrieved from https://cyberleninka.ru/article/n/o-razlichnyh-smyslah-ponyatiya-entropiya [in Russian].

Kornai, J. (1999). Systemic paradigm. Obshchestvo i ekonomiki - Society and the economy, 3-4, 85-96.

Kravchenko, M.O. (2017) Systemno strukturna kontseptsia ekonomichnoi stiykosti pidpriemstv [System-structural concept of economic stability of enterprises]. Kiev: PP Vishemirsky V. S. [in Ukrainian].

Leontyev, B.B. (2015). Obosnovaniye teorii sistemnoy ekonomiki [Justification of the theory of system economics]. Pravovaya informatika - Legal Informatics, 4. Retrieved from https://cyberleninka.ru/article/n/obosnovanie-teorii-sistemnoy-ekonomiki

Leus, V. A. (2003). O heometricheskom obobttschenii entropii [About a geometric generalization of entropy]. Problemy peredachi informatsii - Problems of Information transmission, 2 (39), 15-22 [in Russian].

Lukyanenko, D., Lukyanenko, O., \& Doroshenko, O. (2013). Implementatsiya paradyhmy ekonomiky znan' u stratehiyi natsional'noho ekonomichnoho rozvytku [Implementation of the knowledge economy paradigm in the strategy of national economic development]. Mizhnarodna ekonomichna polityka - International economic policy, 2, 5-26. Retrieved from: http://nbuv.gov.ua/UJRN/Mep_2013_2_3 [in Ukrainian].

Martseva, T.G. (2014). Rynok intellektual'noj sobstvennosti: problemy i perspektivy [Intellectual Property Market: Problems and Prospects]. Vestnik instituta druzhby narodov Kavkaza - Bulletin of the Institute of Friendship of the Peoples of the Caucasus, 4, 611. Retrieved from https://www.idnk.ru/images/vestnik/20144.pdf [in Russian].

Medvedev, V.A. (2005). Kontseptualnoye prostranstvo sotsiologii v formate neklassicheskoy modeli ratsionalnosti [Conceptual space of sociology in the format of a non-classical model of rationality]. Zhurnal sotsiologii $i$ sotsialnoy antropologii - Journal of Sociology and Social Anthropology, 3 (8), 5-21. Retrieved from http://ecsocman.hse.ru/data/638/762/1219/001-Medvedev.pdf

Meyer, K., \& Davis, S. (2007). Zhyvaia orhanizatsyia [Live organization] (A. Stativka, Trans). Moscow: Publishing House «Good Book») [in Russian].

Molchanov, A.M. (1968). Ob odnoy teoreme A. Ya. Khinchina [About a theorem of A. Ya. Khinchin]. IPM Academy of Sciences of the USSR [in Russian].

Muratov, A. S. (2012). Garmonizacionnyj podhod k upravleniju jekonomicheskimi sistemami [Harmonization approach to the management of economic systems]. Upravlenie jekonomicheskimi sistemami - Management of economic systems, 5. Retrieved from http://www.uecs.ru/uecs41-412012/item/1342-2012-05-14-06-38-05 [In Russian]

Muratov, A.S. (2013). Jevoljucija teorii jekonomicheskih garmonij i ego prikladnoe znachenie v upravlenii organizacijami [Thr evolution of the theory economic harmonies and its applied use in organosations management]. Vestnik Kemerovs'kogo gosudarstvennogo universiteta - Vestnik of the Kemerovo State University, 3 (55), 130-140. Retrieved from http://oaji.net/articles/2014/561-1394512281.pdf [In Russian] 
V. Rach, O. Rossoshanska, O. Medvedieva, A. Yevdokymova. System Modelling of Development of Innovative ProjectOriented Enterprises

Neave, G. (2014). Organizatsiya kak sistema: printsipy ustoychivogo postroyeniya biznesa Edvardsa Deminga [Organization as a system: the principles of sustainable business building by Edwards Deming]. (Trans). Moscow: Alpina Publisher [in Russian].

Orekhov, A.M. (2009). Metody ekonomicheskih issledovaniy [Methods of economic research]. Moscow: INFRA-M [in Russian].

Orlov, A.I. (2013). O srednikh velichinakh [About average values]. Upravlenie bol'shimi sistemami - Large systems management, 46. Retrieved from http://cyberleninka.ru/article/n/o-srednih-velichinah. [in Russian].

Osipov, A.I., \& Uvarov A.V. (2004). Entropyia I ii rol v nauke [Entropy and its role in science], Sorosovskij obrazovatel'nyj zhurnal - Soros Educational Journal, 8 (1), 70-79. Retrieved from https://www.twirpx.com/file/1398612 [in Russian].

Ovchinnikiv, Y.L., Yashin, S,S, Tarasenko, D.S, \& Davydkin-Gogel M.M. (2017). tozhdestvennost' zakonov Vebera - Fehnera i Stivensa [Identity Of Laws Of Weber - Fechner And Stevens]. Istochnik: obshchie voprosy mirovoj nauki Mezhdunarodnaja nauchnaja konferencija. Mezhdunarodnaja federacija issledovanij "Science Public» - SOURCE: GENERAL QUESTIONS OF WORLD SCIENCE International Scientific Conference. International Research Federation «Science Public». (pp.8-12). Amsterdam: Konferentsia: https://elibrary.ru/download/elibrary_29829994_56795937.pdf [in Russian].

Palash, S.V. (2017). Strukturnaia sbalansirovanost ekonomiki: hosudarstvinnie prohramy promyshlennoho razvitia d Rosiyskoy Federtsii [Structural Balance of the Economy: State Programs for Industrial Development in the Russian Federation]. Nauchno tekhnicheskie vedomosti Sankt Peterburhskoho hosudarstvennoho politekhnicheskoho universyteta. Ekonomichiskie nauki Scientific and technical reports of the St. Petersburg State Polytechnic University. Economic sciences, 1. Retrieved from https://cyberleninka.ru/article/n/strukturnaya-sbalansirovannost-ekonomiki-gosudarstvennye-programmy-promyshlennogorazvitiya-v-rossiyskoy-federatsii [in Russian].

Petrova, V.A., \& Shadrina, E.I. (2013). Vzaimosvyaz' investicij v R\&D i finansovyh pokazatelej kompanii [Interconnection of investments in R\&D and financial indicators of the company]. Sovremennye naukoemkie tekhnologii - Modern high-tech technologies, 10-2, 201-203. Retrieved from http://www.top-technologies.ru/ru/article/view?id=33425 [in Russian].

Platonova, E.D., Platonov, A.Y., \& Yagodkina, I.A. \& Emelyanov, A.A. (2012). O metodologicheskom resurse sistemnogo issledovaniya ekonomiki [On the methodological resource of systems research of economics]. Internet-zhurnal Naukovedenie Internet Journal Naukovedeni, 4 (13). Retrieved from https://cyberleninka.ru/article/n/o-metodologicheskom-resurse-sistemnogoissledovaniya-ekonomiki [in Russian].

Poljancev, V.A. (1973). Osobennosti metodologii analiticheskogoi sistemnogo podhodov [Features of the methodology of analytical and systemic approaches]. Principy sistemnoj organizacii funkcij - Principles of system organization of functions. (pp. 91 98). Moscow: Nauka [in Russian]

Rach V.A., Medvedeva E.M., Rossoshanskaya O.V., \& Evdokimova A.V. (2011). Innovacionnoe razvitie: model' trojnoj spirali v kontekste sistemnocelostnogo videnija [Innovative development: the triple helix model in the context of systemic vision]. Proceedings from XVI Mizhnarodna naukovo-praktychna konferentsiia «Problemy i perspektivy innovacionnogo razvitija jekonomiki» - The Sixteenth International Scientific and Practical Conference «Problems and Prospects for the Innovation Development of the Economy». (pp. 157-163). Simferopol: IT Arial [in Ukrainian]

Rach, V.A. \& Pilipenko A.I. (2017). Kilkistni metody resursno chasovoho otsiniuvannia $v$ hnuchkiy metodolohii rozrobky prohramnoho zabezpechennia [Quantitative methods of the resource-hourly assessment in the gnuchy methodologies of software development]. Upravlinnia proektamy ta rozvytok vyrobnytsva: zbirnyk naukovyh prats - Project management and development of production:collection of science works, 1 (61), $62-71$ [in Unkrainian].

Romanov, D.B. (2015). Uroki noveyshey istorii Singapura [Lessons from Singapore's Newest History]. Problemy razvitiya territorii- Problems of development of the territory, 6 (80). Retrieved from: https://cyberleninka.ru/article/n/uroki-noveyshey-istoriisingapura [in Russian].

Rossoshanskaya, O.V. (2000).Osobennosti planirovania proektov na osnove systemnoy modeli [Features of project planning based on a system model]. Upravlinnia proektami ta rozvytok vyrobnytstva - Project management and development of production. Lugansk: publishing of SNU named V. Dahl, 1 (1), 57-62 [in Russian].

Rossoshanska, O.V.(2015). Otsinniuvania economichnoi bezpeki innovatsiynikh proektno orientovanikh pidpriemstv [Evaluation of eco-friendly security of inovation design - oriental enterprises]. Severodonetsk: publishing in SNU im. V. Dahl.

Rossoshanska, O.V. (2017). Mekhanizm otsiniuvannia ekonomichnoi bezpeky innovatsiinykh proektno-oriientovanykh pidpryiemstv [Mechanism of estimation of economic safety of innovative project-oriented enterprises]. Upravlinnia proektamy ta rozvytok vyrobnytstva - Project management and production development: Collection of scientific works, 2, 94-122 [in Ukrainian]

Rybachuk, M.A. (2016). Dialektika vzaimodejstviya obshchenauchnyh i disciplinarnyh paradigm (na primere estestvoznaniya ekonomiki) [The dialectic interaction general scientific and disciplinary paradigms (On example of natural science and economics)]. Zhurnal ekonomicheskoj teorii - Journal of Economic Theory, 1, 115-122. Retrieved from https://elibrary.ru/download/elibrary_25590795_63139169.pdf [in Russian]

Samoldin, A.N. (2015). Zhuznenniy tsikl innovatsiy [Life cycle of innovations], Vestnik Gosudarstvenyi universitet upravleniya Vestnik of the State University of Management, 2. Retrieved from https://cyberleninka.ru/article/n/zhiznennyy-tsikl-innovatsiy.

Senatorov, Yu.M.(2018). Podhody k ponimaniu sushchnosty informatsii [Approaches to understanding the essence of information]. Kontekst i refleksiia: filosofia o mire i cheloveke - Context and reflection: a philosophy about the world and man, $1 \mathrm{~A}$ (7), 5-20. Retrieved from http://publishing-vak.ru/file/archive-philosophy-2018-1/1-senatorov.pdf [in Russian].

Senge, P. (2009). Pyataya distsiplina. Iskusstvo i praktika obuchayushcheysya organizatsii [Fifth Discipline. Art and practice of the learning organization]. (B.Pincker, I. Tatarinova, Trans). Moscow: ZAO «Olymp-Business» [in Russian]. 
V. Rach, O. Rossoshanska, O. Medvedieva, A. Yevdokymova. System Modelling of Development of Innovative ProjectOriented Enterprises

Sharipova, O.S., \& Nadion, G.O. (2012). Garmonizacija dijal'nosti jak proces zabezpechennja ekonomichnoï bezpeki pidpriemstva [Harmonization of activities as a process of ensuring the economic security of the enterprise]. Upravlinnya proektamy ta rozvy'tok vy 'robny'cztva - Project management and production development, 1 (41), 50-55 [In Ukrainian]

Skryl', T.V. (2008). Formirovanie informatsionnoho sektora ekonomiky: teoretyko metodolohycheskiy aspekt [Formation of the Information Sector of the Economy: Theoretical and Methodological Aspect]. Vestnik THU - Messenger of TGU, 4. Retrieved from https://cyberleninka.ru/article/n/formirovanie-informatsionnogo-sektora-ekonomiki-teoretiko-metodologicheskiy-aspekt [in Russian].

Smorodinskaya, N. (2011). Troynaya spiral' kak novaya matritsa ekonomicheskikh sistem [The Triple Helix as a New Matrix of Economic Systems]. Innovation, 4. Retrieved from: https://cyberleninka.ru/article/n/troynaya-spiral-kak-novaya-matritsaekonomicheskih-sistem [in Russian].

Soroko, E.M. (2011). Innovatsionnaya sutschnost zakonostrukturnoy harmonii i kohnitivnyh tehnolohiy na puti ot lohikotsentrisma k systemotsentrizmu: postizhenie sutschnosty ustoychevykh sostoianiy obtschestva i obespechenia bezopastnosty eho ekonomiky [Innovative essence of law-harmonious harmony and cognitive technologies on the way from logical centrism to system-centrism: comprehension of the essence of steady state of society and ensuring the security of its economy]. Ekonomicheskaia bezopastnost: novaia paradyhma formirivania i obespechenia - Economic security: new paradigma formation and support. Edited by EM. Soroko, I.V. Belousova, T.I. Egorova-Gudkova. Oдecca: Institut kreativnyh tehnoloij, (pp. 22-110).

Sytnikov, V.V. (2012). Systemna paradyhma v sektoral'niy sferi ekonomiky [System paradigm in the sectoral economy]. Stratehiya rozvytku Ukrayiny. Ekonomika, sotsiolohiya, pravo - Strategy of development of Ukraine. Economics, sociology, law, 1 , 228-232. Retrieved from http://jrnl.nau.edu.ua/index.php/SR/article/view/6130/6860 [in Ukrainian]

Shhedrovickii, G.P., \& Zinchenko A.P. (2012). Putivoditel po metodologii Orhanizatsii, Rukovodstva I Upravleniia. [Guidebook on the methodology of the Organization, Direction and Management]. Moscow: Alpina Publisher [in Russian].

Vartsaba, V.I. (2015). Kategoriya interesu yak ob'yekt garmonizovanogo upravlinnya i menedzhmentu [Category of interest as an object of harmonized management and management]. Ekonomichny'j analiz - Economic analysis, 1 (21), 15-25. Ternopil': Ekonomichna dumka [In Ukrainian]

Vladimirov, V., \& Stakhov A. Entropia zolotoho sechenia (raskryta etsche odna taina zolotoho sechenia) [Entropy of the golden section (one more mystery of the golden section is revealed)]. Retrieved from http://w.trinitas.ru/rus/doc/0232/009a/1199-ent.pdf

Voitko, S.V., \& Kravchenko, M.O. (2017). Analiz mekhanizmu formuvannya ekonomichnoyi stiykosti mashynobudivnykh pidpryyemstv (neosystemnyy pidkhid) [The analysis of the mechanism of formation of economic stability of machine-building enterprises (non-system approach)]. Marketynh i menedzhment innovatsiy - Marketing and Innovation Management, 2, 211-221.

Voroshan, A.D. (2014). Systemna ekonomika yak platforma rozvytku suchasnoyi ekonomichnoyi teoriyi [System economics as a platform for the development of modern economic theory]. Naukovyy visnyk Bukovyns'koho derzhavnoho finansovoekonomichnoho universytetu - Scientific Bulletin Bukovinsky State Financial-Economic University. Economic Sciences, 27, 423429.Retrieved from http://nbuv.gov.ua/UJRN/Nvbdfa_2014_27_65 [in Ukrainian].

Vyatkin, V.B., Zadacha otsenky nehentropii otrazhenia systemnykh obiektov $\mathrm{i}$ tradytsionnye podhody $\mathrm{k}$ kolichistvennomu opredeleniu informatsii TThe problem Of Evaluation of Ngentropy Reflection Of System Objects and Traditional Approaches To Quantitative Determination Of Information]. Retrieved from http://vbvvbv.narod.ru/problemnegentropy/combinatory/index.html

Zemtsov, S.P, \& Barinova, V.A. Innovatsionniy tsikl kak bazovaya model dinamiki i orhanizatsii innivatsionnoy deiatiolnost [Innovation cycle as the basic model of dynamics and organization of innovation activity]. Vestnik Instituta economiki Rosiyskoy akademii nauk, 1, 117-127. Retrieved from https://www.ranepa.ru/mages/docs/nayka/Barinova_02.pdf [in Russian].

В. А. Рач, д.т.н., профресор, університет КРОК (Україна);

О. В. Россошанська, д.е.н., доцент, Луганська академія культури та мистецтв (Україна);

О. М. Медведєва, д.т.н., профессор, університет КРОК (Україна);

А. В. Євдокимова, к.т.н., Сумський державний університет (Україна).

Системне моделювання розвитку інноваційних проектно-орієнтованих підприємств

У статті узагальнені аргументи та контраргументи в межах наукової дискусії з питання кількісного оцінювання різних сфрер діяльності підприємств на основі їх системного представлення. Основною метою проведеного дослідження є удосконалення базової моделі системної економіки як основи для розроблення методу кількісного оцінювання гармонійності процесів розвитку інноваційних проектно орієнтованих підприємств. Систематизація літературних джерел та підходів до вирішення проблеми вибору базової моделі засвідчила, що найбільш обгрунтованим та розвинутим є підхід, який базується на моделі економічної тетради. Модель використовувалась різними авторами при розробці показників збалансованості та стійкості економічних систем. Але відомі результати не порівнювались між собою, а модель не застосовувалась для опису інноваційного розвитку підприємств. Актуальність вирішення даної наукової проблеми полягає в тому, що в епоху економіки знань інноваційний розвиток стає одним з головних напрямків діяльності сучасних підприємств, який потребує наукового забезпечення цього виду діяльності. Дослідження 
V. Rach, O. Rossoshanska, O. Medvedieva, A. Yevdokymova. System Modelling of Development of Innovative ProjectOriented Enterprises

питання розробки методу кількісного оцінювання процесів розвитку інноваційних проектноорієнтованих підприємств в статті здійснено в наступній логічній послідовності: приведення до вимог системної цілісності та повноти економічної тетради; проведення аналіз взаємообміну ресурсами у тріадах економічної тетради; розкриття сутності механізму управління процесами зростання та розвитку підприємств; розробка математичного апарату опису динамічних структурних змін, які відбуваються на підприємствах; приведення комп'ютерного експерименту із застосуванням п'яти різних підходів до розрахунку показників динамічних структурних змін під час впровадження інновацій; проведення порівняльного аналізу отриманих результатів. Об'єктом дослідження обрані фрази життєвого циклу інноваційного проекту, оскільки саме вони визначають особливості динамічних структурних змін, які відбуваються на підприємствах під час впровадження інновацій. В статmі представлено результати емпіричного аналізу, який проведено на основі даних комп'ютерного моделювання реалізації інноваційного проекту за шістьма різними підходами, який засвідчив принципово різний характер зміни показників структурної збалансованості для цих підходів. Дослідження емпірично підтверджує та теоретично доводить, що запропонований показник внутрішньої узгодженості протилежних дій (хаотичних та організованих) відповідає логіці гармонійної реалізації інноваційної діяльності. Результати проведеного дослідження можуть бути корисними для розробки систем моніторингу та управляння процесами розвитку інноваційних проектно-орієнтованих підприємств

Ключові слова: імпліцитні явища, збалансованість, гармонія, метод потрійного згортання, інноваційний проект.

Manuscript received: 16.11 .2018

(c) The author(s) 2019. This article is published with open access at Sumy State University. 